Freitas, B.T., et al., 2021, Cryogenian glaciostatic and eustatic fluctuations and massive Marinoan-related deposition of Fe and Mn in the Urucum District, Brazil: Geology, v. 49, https://doi.org/10.1130/G49134.1

\title{
DESCRIPTION OF METHODS
}

\section{Field methods}

Detailed mapping and sedimentary logging of the Jacadigo Group in the Urucum (Figs. S1A-S1E) provided the basis for the facies and stratigraphic analyses discussed in the main text. Nine measured stratigraphic sections (Fig. S1E) were selected from a larger dataset to illustrate the sedimentary sequences recognized in the Urucum district (Fig. 1, main text). Complementary illustrations of sedimentary features underpinning the interpretations presented in the manuscript are given in figures $\mathrm{S} 2$ to S5. Locations of the sedimentary features displayed in Fig. 4 (main text) are: 4A, TQ area (Fig. S1); 4B and 4F, CP section (Fig. S1) and UC.01 section in Freitas et al. (2011); 4C, SC section (Fig. S1); 4D, CP section (Fig. S1) and SD.01 section in Freitas et al. (2011); 4E, ZN.02 section in Freitas et al. (2011).

\section{Carbon and oxygen isotope analysis}

Seventy-two samples of carbonate rock were analyzed for stable carbon and oxygen isotopes at the Geochronological Research Center (CPGeo) of the University of São Paulo and 26 other samples (TQ 01 A-T) were analyzed at the Stable Isotope Laboratory of the Federal University of Pernambuco (LABISE) (Table S1). Carbonate powder was obtained by microdrilling of homogeneous areas devoid of late diagenetic features. For these analyses, carbonate powder was reacted with $100 \% \mathrm{H}_{3} \mathrm{PO}_{4}$ at $72^{\circ} \mathrm{C}$ under a $\mathrm{He}$ atmosphere for samples at $\mathrm{CPGeo}$. $\mathrm{C}$ and $\mathrm{O}$ isotopic composition of the extracted $\mathrm{CO}_{2}$ was then measured in a Delta Advantage mass spectrometer. The results of isotopic compositions are reported in the delta ( $\delta$ ) notation, relative to the Vienna Pee Dee belemnite standard (VPDB). Instrumental precision was $\pm 0.05 \%$ and $\pm 0.07 \%$ for $\delta^{13} \mathrm{C}$ and $\delta^{18} \mathrm{O}$, respectively. Samples at LABISE were reacted with $100 \%$ orthophosphoric acid at $25^{\circ} \mathrm{C}$ for one hour for calcite samples and 72 hours for dolomite powder. The extracted $\mathrm{CO}_{2}$ isotopic composition was measured in a double inlet, triple collector mass spectrometer (VG Isotech SIRA II). Instrumental precision was below $0.1 \%$ for $\mathrm{C}$ and $\mathrm{O}$.

\section{Major and trace elements}

$\mathrm{Ca}, \mathrm{Mn}, \mathrm{Fe}$, and $\mathrm{Sr}$ content (Table S2) were determined by X-ray fluorescence (XRF) in 44 samples of carbonate rocks to assess post-depositional alteration of carbon and oxygen isotope compositions. XRF analyses were carried out with a portable Olympus Delta XRF Analyzer in the Marine Inorganic Chemistry Laboratory of the Institute of Oceanography at the University of São Paulo. Slabs of the carbonate rocks were polished and the most homogeneous surfaces selected for XRF analysis. A blank (pure $\mathrm{SiO}_{2}$ ) and the reference material NIST SRM 2711A were measured after every 20 samples. Ca, Mn, Fe, and Sr contents of the blank were below detection limits of the equipment. Based on 35 measurements of the standard material NIST SRM 2711A, average uncertainties are below \pm $0.4 \%$ for $\mathrm{Ca}$ and $\mathrm{Fe}, \pm 92 \mathrm{mg} / \mathrm{kg}$ for $\mathrm{Mn}$ and below $\pm 7 \mathrm{mg} / \mathrm{kg}$ for Sr. Results are reproducible within a range of $\pm 0.05 \%$ for $\mathrm{Ca}$ and $\mathrm{Fe}, \pm 9 \mathrm{mg} / \mathrm{kg}$ for $\mathrm{Mn}$, and $\pm 5 \mathrm{mg} / \mathrm{kg}$ for Sr. 


\section{Detrital zircon geochronology}

\section{LA-ICP-MS Analysis}

Sampling was carried out over distinct intervals of post-Sturtian successions from the Urucum Formation at the margins and center of the Urucum district (Fig. S1). Sample preparation and analysis were conducted at the Institute of Geosciences, University of Campinas, Brazil. Rock samples were jaw crushed and sieved. The sieved fraction was panned, and zircon grains were separated from magnetic minerals using a hand-magnet. Zircon grains were randomly handpicked under a binocular microscope, then fixed in epoxy resin discs that were sanded and polished, exposing a cross section of each zircon grain.

Morphology and texture of zircon grains were investigated through Backscattered Electron (BSE) and Cathodoluminescence (CL) images. LA-ICP-MS analyses were done with an Excite.193 (Photon Machines) laser ablation system, equipped with a two-volume HelEx ablation cell, coupled with an ICP-MS Element XR (Thermo Scientific). Laser diameter was adjusted to $25 \mu \mathrm{m}$ with an acquisition time of 40s. Measured isotopic ratios were monitored using the zircon standards 91500, Plešovice and PEIXE (Wiedenbeck et al., 1995; Sláma et al., 2008; Navarro et al., 2017) (Table S3, separate file). Data were processed using the Software Iolite 2.5, following the method described by Paton et al. (2010). Because ${ }^{204} \mathrm{~Pb}$ signals were extremely weak in almost all grains, common lead correction was not performed and grains with anomalous ${ }^{204} \mathrm{~Pb}$ signals were not considered. LA-ICP-MS ages are given with $2 \sigma$ uncertainties (Table S3).

\section{SHRIMP Analysis}

Sample preparation and analysis were performed at the Institute of Geosciences, University of São Paulo, Brazil, using standard separation methods (crushing, sieving, magnetic separation, and heavy liquids separation). Grains were handpicked under a binocular microscope and fixed in an epoxy resin mount. Grain morphology was investigated by Cathodoluminescence (CL) imaging. Common lead was corrected based on ${ }^{204} \mathrm{~Pb}$ measurements. Measurements were calibrated using the TEMORA standard (Black et al., 2003) (Table S3). Further details about equipment, data processing and analytical procedures are described by Sato et al. (2014). Ages obtained by SHRIMP are given with $1 \sigma$ uncertainties (Table S3).

\section{Data Filtering}

Concordia Plots were made with IsoplotR (Vermeesch, 2018). Grains that yielded a concordant age but apparently aligned along a discordia line were not considered in the Probability Density Plots. The Probability Density Plots were generated using detritalPy (Sharman et al., 2018) (Fig. 3, main text). Ages older than $1000 \mathrm{Ma}$ and younger than 1000 Ma are reported using the ${ }^{207} \mathrm{~Pb} /{ }^{206} \mathrm{~Pb}$ and ${ }^{206} \mathrm{~Pb} /{ }^{238} \mathrm{U}$ ages, respectively. Only ages with discordance and reverse discordance less than 10\% were considered (Table S3). 


\section{SUPPLEMENTAL TEXT}

\section{Chronostratigraphic framework for the Jacadigo Group}

The Cryogenian timeframe proposed here for the Jacadigo Group is based on our interpretation that the basal and upper portions, separated by a thick package of carbonates topped by a regional unconformity, exhibit clear evidence of glacial influence in two distinct events. A glacial influence upon initial deposition of S1 is inferred from glaciotectonic and sedimentological evidence: (i) locally restricted fractures filled by poorly sorted feldspathic sedimentary rock at the top of the basement (Fig. 4, main text; Figs. S2A-S2C); (ii) abundant jig-saw fitted clasts and meter-scale crystalline basement fragments in poorly sorted basal deposits of S1 (Fig. 4A and 4B, main text; Figs. S2F, S2G; and Fig. 6D in Freitas et al., 2011); (iii) sigmoidal clusters of fitted clasts, locally displaying grooves (Fig. 4A, main text; Fig. S2F); and (iv) bullet-shaped clasts in boulder-grade breccia/diamictite (Fig. 4B, main text). The glacial influence upon deposition of the upper sequence of the Jacadigo Group (S2) is confirmed by the presence of outsized clasts (dropstones) deforming underlying beds and by other supporting sedimentary evidence presented here and in the main text (Fig. 4D-4F, main text; Figs. S4A-S4F; S5C, S5E, and S5F).

We reject a tectonic (cataclastic) origin for the features at the base of the Jacadigo Group for several reasons. First, the crystalline basement and the overlying poorly sorted sedimentary deposits are mostly undeformed and unmetamorphosed. The deformational features shown in figures 4A (main text), S2F, and S2G, are local phenomena that closely resemble bedrock deformation features attributed to glacial activities previously described by Broster et al. (1979), Harris et al. (1991) and Van der Wateren et al. (2000). Likewise, as observed along the interface of Cenozoic till and bedrock south of Cranbrook, British Columbia (Broster et al., 1979), the unconformity at the base of S1 is not always clearly defined because of the density of local fracturing and sediment infilling. Cenozoic glacial deposits also include jig-saw fitted clasts, explained as forming when chunks of frozen substrate are plucked and transported by ice (Williams \& Tonkin, 1985; Czudek, 1995; Passchier et al., 1998), and are locally associated with sigmoidal, sheared deposits displaying grooves (Fig. 4A, main text; Fig. S2F) in lodgment till deposits (Harris, 1991, Van der Wateren et al., 2000).

Clear evidence of glacial influence for two distinct Neoproterozoic sequences with glacial deposits separated by a thick carbonate succession allows us to consider two principal chronostratigraphic hypotheses for the Jacadigo Group sedimentary record, first, that the two Neoproterozoic glaciations at the Urucum district might represent, respectively, the Marinoan (Late Cryogenian, 650-635 Ma) and the short-lived Gaskiers (mid-Ediacaran, c. $580 \mathrm{Ma}$ ) glaciations. This would be consistent with the correlation of the large acanthomorphic acritarchs observed in S1 carbonates of the Urucum Formation (Fig. S3B) with those near the base of the post-Marinoan cap carbonate of the Doushantuo Formation (635-590 Ma) (Xiao et al., 1998) in China. This, however, would place the age of banded iron formation in S2 at about $580 \mathrm{Ma}$, which is difficult to reconcile with the $587 \pm 7 \mathrm{Ma}$ age for strong diagenesis or anchimetamorphism in cryptomelane of the Mn-rich beds within this same banded iron formation (Piacentini et al., 2013). 
The second, preferred interpretation for deposition of the Jacadigo sedimentary record is that it began during the Sturtian glaciation (716-658 Ma), followed by deposition of the carbonate succession and subsequent erosion during the Cryogenian interglacial interval, and terminating with deposition of S2 with its thick banded iron formation during the decline of the Marinoan glaciation ( 650-635 Ma). This interpretation is also supported by chemostratigraphic correlation of the transgressive carbonate successions and source area evolution recorded in the Jacadigo Group (see below).

\section{Stable isotope and $\mathrm{XRF}$ results}

In $\mathrm{S} 1, \delta^{13} \mathrm{C}$ values vary from -0.21 to $+8.50 \%$ in a positive excursion. $\delta^{18} \mathrm{O}$ values range from -10.58 to $+1.01 \%$ with the heavier isotope compositions observed more frequently in columnar sections TQ2 and TQ1 (Fig. 2, main text), interpreted as shallow water, proximal, shelf deposits. The near $0 \% \delta^{13} \mathrm{C}$ value obtained between 36 and $42 \mathrm{~m}$ in section TQ2 is from a carbonate clast of a carbonate breccia lens probably derived from the resedimentation of shallower deposits basinward. This localized shift to lower $\delta^{13} \mathrm{C}$ values is not interpreted as a negative excursion. In $\mathrm{S} 2, \delta^{13} \mathrm{C}$ values vary from -1.81 to $+2.54 \%$ in a second positive excursion above the middle diamictite deposits in columnar section TQ1. $\delta^{18} \mathrm{O}$ values range from -9.52 to $-4.68 \%$ in a negative excursion (Fig. 2, main text).

TQ1 average iron content is $0.22 \%$ in S1 and $0.20 \%$ in S2. Average Mn content is 702 $\mathrm{mg} / \mathrm{kg}$ in $\mathrm{S} 1$ and $668 \mathrm{mg} / \mathrm{kg}$ in S2. Sr contents are low, with averages of 99 and $85 \mathrm{mg} / \mathrm{kg}$ in $\mathrm{S} 1$ and S2, respectively, resulting in high $\mathrm{Fe} / \mathrm{Sr}$ and $\mathrm{Mn} / \mathrm{Sr}$ ratios for the proximal carbonate shelf deposits of the Jacadigo Group. Average Fe/Sr ratio is 32 in S1 and 27 in S2, whereas average $\mathrm{Mn} / \mathrm{Sr}$ ratio is 12 in $\mathrm{S} 1$ and 9 in S2. Low contents of Fe and Mn are recorded in TQ2 (S1), with averages of $0.07 \%$ and $88 \mathrm{mg} / \mathrm{kg}$, respectively. Sr contents are low, with an average of $53 \mathrm{mg} / \mathrm{kg}$. TQ2 Fe/ $\mathrm{Sr}$ and $\mathrm{Mn} / \mathrm{Sr}$ ratios are lower, with averages of 17 and 2, respectively, when compared with the proximal TQ1 section.

Carbonate rocks from distal S1 shelf to slope deposits, as recorded in the SC section (Fig. 2, main text), presented lower Fe and Mn contents (averages of $0.11 \%$ and $58 \mathrm{mg} / \mathrm{kg}$, respectively) compared to the proximal deposits recorded in the TQ1 and TQ2 sections. Sr contents are low in SC (average of $55 \mathrm{mg} / \mathrm{kg}$ ), resulting in low $\mathrm{Fe} / \mathrm{Sr}$ and $\mathrm{Mn} / \mathrm{Sr}$ ratios with averages of 18 and 1, respectively.

\section{Post-depositional alteration of isotope signatures}

The dynamics of isotope, trace and major elements during carbonate diagenesis are here assessed through the relationships among $\delta^{18} \mathrm{O}, \delta^{13} \mathrm{C}, \mathrm{Fe} / \mathrm{Sr}, \mathrm{Mn} / \mathrm{Sr}$ and $\mathrm{Ca} / \mathrm{Sr}$ in the studied sedimentary sequences (e.g. Hudson, 1977; Banner \& Hanson, 1990; Kah, 2000; Folling \& Frimmel, 2002). Carbonate rocks from S1 in TQ1 (Fig. 2, main text) present a moderate positive correlation for $\delta^{18} \mathrm{O} v \mathrm{vs} \delta^{13} \mathrm{C}(\mathrm{r}=0.64, \mathrm{p}(\alpha)>0.01)$ (Fig. S6A), suggesting some meteoric influence in these proximal carbonate rocks. However, there is neither a clear trend in $\mathrm{Mn}$ vs $\mathrm{Sr} / \mathrm{Ca}$ relationships (Fig. S6B), nor between $\mathrm{Sr} / \mathrm{Ca}, \mathrm{Fe} / \mathrm{Sr}$ and $\mathrm{Mn} / \mathrm{Sr}$ ratios and isotope values (Figs. S6C-S6H) that would indicate overprinting of isotopic signatures by meteoric fluids. S2 carbonates in TQ1 (Fig. 2, main text) display a strong negative correlation between $\delta^{18} \mathrm{O}$ and $\delta^{13} \mathrm{C}(\mathrm{r}=-0.85, \mathrm{p}(\alpha)<0.01)$ (Fig. S6A), also evident in the antithetical behavior of the isotope excursions (Fig. 2, main text). $\mathrm{Sr} / \mathrm{Ca}$ slightly decreases in samples with higher Mn content (Fig. S6B), negative $\delta^{13} \mathrm{C}$ (Fig. S6C) and heavier $\delta^{18} \mathrm{O}$ values (Fig. 
S6D), suggesting some effect of meteoric fluids and/or dolomitization in a shallow evaporative environment. Increase in $\mathrm{Mn} / \mathrm{Sr}$ and $\mathrm{Fe} / \mathrm{Sr}$ ratios are coupled with negative $\delta^{13} \mathrm{C}$ and heavier $\delta^{18} \mathrm{O}$ values (Figs. S6E-S6H), which are also likely associated with meteoric influence and/or dolomitization.

Carbon and oxygen isotope values from S1 recorded in columnar section TQ2 (Fig. 2, main text) display a weak positive correlation between $\delta^{18} \mathrm{O}$ and $\delta^{13} \mathrm{C}(\mathrm{r}=0.18, \mathrm{p}(\alpha)>0.01)$ (Fig. S6A), and no relationship between $\mathrm{Sr} / \mathrm{Ca}$ ratios and Mn contents (Fig. S6B). However, a slight increase in $\mathrm{Fe} / \mathrm{Sr}$ and $\mathrm{Mn} / \mathrm{Sr}$ ratios are associated with the lighter $\delta^{13} \mathrm{C}$ and heavier $\delta^{18} \mathrm{O}$ values, respectively (Figs. S6E-S6H). This increase in such ratios may represent some influence of meteoric fluids and/or dolomitization in a shallow evaporative environment for this section. Carbonates from S1 in the SC section (Fig. 2, main text) presented weak negative correlation between $\delta^{18} \mathrm{O}$ and $\delta^{13} \mathrm{C}(\mathrm{r}=-0.36, \mathrm{p}(\alpha)>0.01)$ (Fig. S6A) and a lack of correlation between $\mathrm{Sr} / \mathrm{Ca}$ ratio and $\mathrm{Mn}$, as well as between $\mathrm{Sr} / \mathrm{Ca}, \mathrm{Fe} / \mathrm{Sr}$ and $\mathrm{Mn} / \mathrm{Sr}$ ratios and carbon and oxygen isotope values (Figs. S6B-S6H). These observations allied with the lowest values for $\mathrm{Fe} / \mathrm{Sr}$ and $\mathrm{Mn} / \mathrm{Sr}$ suggest these carbonate rocks are the best preserved in the studied carbonate succession, as one would expect for the distal domains of the carbonate platform, away from continental influence.

As a conclusion, the geochemical relationships presented above suggest a progressive lack of meteoric/dolomitization influence over isotope signatures from TQ 1 to SC (Fig. 2, main text), with SC carbonates presenting the best-preserved primary isotope signatures. Notwithstanding, even considering some degree of diagenetic influence upon the isotope signatures recorded in sections TQ1 and TQ2, the positive trends from 0 to $+8 \%$ recorded along $\mathrm{S} 1$ in all studied sections argue for a primary control over these carbon isotope excursions. The same is true for the S2 carbon isotope excursion recorded only in the TQ1 section. Despite the diagenetic overprint interpreted from $\mathrm{Mn} / \mathrm{Sr}$ and $\mathrm{Fe} / \mathrm{Sr}$ ratios coupled with negative $\delta^{13} \mathrm{C}$ values, the $\mathrm{S} 2$ isotope signals are also typical and potentially inherited from post-glacial cap carbonate deposition, as detailed below.

\section{Correlation of carbon isotope excursions}

A carbonate succession displaying a positive carbon isotope excursion reaching $\delta^{13} \mathrm{C}$ values up to $+8.50 \%$, between two intervals of glacially influenced deposits both limited at their bases by regional erosional unconformities, is correlated to mid-Cryogenian, postSturtian, interglacial, carbonate successions typically displaying heavy carbon isotope compositions (Halverson \& Shields-Zhou, 2011) (Fig. S7). The lack of a negative $\delta^{13} \mathrm{C}$ peak within the interglacial S1 does not allow specifically positioning of the positive excursion (Fig. S7). It could be related either to the positive excursion right after the post-Sturtian cap carbonate interval, before the Taishir negative anomaly, or to the positive excursion associated with the positive $\delta^{13} \mathrm{C}$ Keele peak preceding the Trezona anomaly (Halverson \& Shields-Zhou, 2011; Shields-Zhou et al., 2016; Ogg et al., 2016) (Fig. S7). Besides these high $\delta^{13} \mathrm{C}$ values typical of the Late Cryogenian Warm Interval (Shields-Zhou et al., 2016 and references therein), in NE Svalbard, a coeval dolomitized carbonate succession bears features of evaporitic environments, an interpretation equally applicable to the S1 carbonates of TQ1 and TQ2 from their relatively high $\delta^{18} \mathrm{O}$ values ( -4 to $+1 \%$ ) (Fig. 2, main text).

A second positive $\delta^{13} \mathrm{C}$ excursion right above the second level of glacially influenced deposits recorded in TQ1 is here correlated to the Marinoan cap carbonate interval (Fig. S7). 
The absence of more negative $\delta^{13} \mathrm{C}$ values usually found in Marinoan cap carbonates (Halverson \& Shields-Zhou, 2011) could be associated with a hiatus between the end of diamictite deposition and the post-glacial carbonate record in TQ1, with the lowest $\delta^{13} \mathrm{C}$ value at $-2 \%$. This interpretation could also explain the lack of typical sedimentary structures observed in Marinoan cap carbonates, such as aragonite crystal fans and giant wave ripples (e.g. Hoffman \& Schrag, 2002).

Increased $\mathrm{Fe} / \mathrm{Sr}$ and $\mathrm{Mn} / \mathrm{Sr}$ ratios throughout $\mathrm{S} 2$ are geochemical features also commonly observed in cap carbonate successions worldwide, which could be related to a globally diachronous early diagenesis due to intense meteoric influence in this post-glacial interval (e.g. Knauth \& Kennedy, 2009). In this sense, the carbonate succession in S2 may well be correlated to occurrences of post-Marinoan cap carbonates recognized in the South Paraguay Belt (Romero et al., 2016), as, for example, in the nearby Puga hill, where carbonate deposits overlying diamictites in the type section of the Puga Formation display $\delta^{13} \mathrm{C}$ values as low as $-5 \%$ and ${ }^{87} \mathrm{Sr} /{ }^{86} \mathrm{Sr}$ ratios of 0.7077 (Boggiani et al., 2003; Babinski et al., 2013).

\section{Detrital zircon geochronology results}

LA-ICP-MS analysis (Samples MJ17-1(9), MJ17-1(1)B, MAR17-2(6), MAR17-2(8), CP1702B, MRB-17-2(2), NR 123 and TQ-18)

A total of 1205 grains were analyzed by LA-ICP-MS technique. 911 grains $(75,8 \%)$ met the criteria established in the methods section. Fractures and mineral inclusions in zircon grains were avoided using Cathodoluminescence (CL) and Backscattered Electron (BSE) images. Samples are described in detail below.

\section{Sample MJ17-1(9) - Breccia}

Sample MJ17-1(9) is a poorly sorted sandy breccia with carbonate clasts near the base of S2, which is near the base of the Urucum Formation at Jacadigo hill (MJ section, Fig. S1). Of the 175 grains analyzed, only 37 (25\%) met the criteria established in the methods section. Grains are mostly sub-rounded with low sphericity, ranging from $30 \mu \mathrm{m}$ to $230 \mu \mathrm{m}$ in size, with a predominance of grains in the fine sand fraction (Fig. S8A). The sample has only one expressive age peak, with ages ranging from 1700 Ma to 1800 Ma (Fig. 3, main text; Fig. S9A).

\section{Sample MJ17-1(1)B - Shale}

This shale sample is from the upper Urucum Formation at Jacadigo hill (MJ section, Fig. S1). Of the 172 grains analyzed, 74 (43\%) met the criteria established in the methods sections. Grains are mostly sub-angular or sub-rounded with low sphericity, ranging from 40 $\mu \mathrm{m}$ to $120 \mu \mathrm{m}$ in size, with a predominance of grains in the very fine sand fraction (Fig. S8B). Most grains are broken, and transparent pinkish grains are abundant. Ages cluster around two peaks in the PDP (Fig. 3, main text), one from $600 \mathrm{Ma}$ to $900 \mathrm{Ma}$ and the other from $1800 \mathrm{Ma}$ to $1900 \mathrm{Ma}$ (Fig. S9B). This sample yielded the youngest concordant age $690 \pm 18 \mathrm{Ma}-$ of all the grains in our analysis. 


\section{Sample MAR17-2(6) - Heterolithic deposits}

This sample is a heterolithic siliciclastic rock from the middle part of the Urucum Formation at Rabicho hill (MAR section, Fig. S1). Of 158 grains analyzed, 126 (80\%) met the criteria established in the methods section. Grains are mostly sub-rounded with low sphericity, ranging from $50 \mu \mathrm{m}$ to $200 \mu \mathrm{m}$ in size with grains predominantly in the fine sand fraction (Fig. S8C). The sample exhibits one large peak with ages ranging from $1800 \mathrm{Ma}$ to $1900 \mathrm{Ma}$ and few ages outside this interval (Fig. 3, main text; Fig. S9C).

\section{Sample MAR17-2(8) - Sandstone}

This sandstone is from the base of the Urucum Formation at Rabicho hill (MAR section, Fig. S1). Of 123 grains analyzed, 66 (54\%) fulfilled the criteria established in the methods section. Grains are mostly sub-rounded with low sphericity, ranging from $50 \mu \mathrm{m}$ to $200 \mu \mathrm{m}$ in size, and predominantly in the fine sand fraction (Fig. S8D). This sample shows an age peak from $1800 \mathrm{Ma}$ to $1900 \mathrm{Ma}$ but also presents a small number of grains with Mesoproterozoic ages (Fig. 3, main text; Fig. S9D).

\section{Sample CP17-02B - Heterolithic deposits}

This is a heterolithic siliciclastic rock from the middle section of the Urucum Formation at the center of the Urucum District (CP section, Fig. S1). Of 135 grains analyzed, 132 (98\%) exhibited discordance below 10\%. No grain was excluded due to Pb loss. Grains are mostly sub-rounded with low sphericity, ranging from $50 \mu \mathrm{m}$ to $200 \mu \mathrm{m}$ in size, with grains predominantly in the fine sand or very fine sand fraction (Fig. S8E). This sample exhibit two peaks, a large one at $1700 \mathrm{Ma}$ to $1800 \mathrm{Ma}$ and a small one at $1800 \mathrm{Ma}$ to 1900 Ma. A small number of grains of Mesoproterozoic age is also present (Fig. 3, main text; Fig. S9E).

\section{Sample MRB-17-2(2) - Diamictite}

This sample represents the matrix of a diamictite from northernmost Rabicho hill, near the Paraguay River (NR section, Fig. S1). Of 185 grains analyzed, 182 (98\%) met the criteria established in the methods section. Grains are mostly sub-rounded to rounded with low sphericity, ranging from $50 \mu \mathrm{m}$ to $200 \mu \mathrm{m}$ in size with a predominance of grains in the very fine sand fraction (Fig. S8F). This sample has a single peak, with ages ranging from $1700 \mathrm{Ma}$ to $1900 \mathrm{Ma}$ (Fig. 3, main text; Fig. S9F).

\section{Sample NR 123 - Heterolithic deposits}

This sample is from the heterolithic beds overlying the diamictite at northern Rabicho hill (NR section, Fig. S1). Of 186 grains analyzed, 177 yielded concordant ages. No grain was excluded due to $\mathrm{Pb}$ loss. Grains are mostly sub-rounded with low sphericity, ranging from $60 \mu \mathrm{m}$ to $200 \mu \mathrm{m}$ in size, with a predominance of grains in the very fine sand fraction (Fig. S8G). This sample is dominated by grains between 1800-1900 Ma in age with subordinate Mesoproterozoic populations (Fig. 3, main text; Fig. S9G). 


\section{Sample TQ-18 - Carbonate deposits}

This is a stromatolitic dolomite sample from the carbonate shelf deposits at Taquaral hill (TQ2 section, Fig. S1). Of 128 grains analyzed, 117 (91\%) met the criteria established in the methods section. Grains are mostly sub-rounded to rounded with low to medium sphericity, ranging from $30 \mu \mathrm{m}$ to $180 \mu \mathrm{m}$ in size, predominantly in the very fine sand fraction (Fig. S8H). Most grains are broken. This sample has only one age peak, between $1700 \mathrm{Ma}$ and $1800 \mathrm{Ma}$ (Fig. 3, main text; Fig. S9H).

\section{SHRIMP analysis (Sample LM16)}

This sample is from VSM-bearing carbonate clasts within diamictite near the base of the Urucum Formation at Rabicho hill (NR section, Fig. S1). Of the 67 grains analyzed, 46 met the criteria established in the methods section. Grains are sub-angular to sub-rounded with medium sphericity, ranging from $45 \mu \mathrm{m}$ to $240 \mu \mathrm{m}$ in size, predominantly in the fine sand fraction (Fig. S10). Most grains are broken. This sample exhibit only one age peak, between $1800 \mathrm{Ma}$ and $1900 \mathrm{Ma}$ (Fig. 3, main text; Fig. S11).

\section{Detrital zircon provenance}

Zircon grains with ages between 1700 and $1900 \mathrm{Ma}$ are a major constituent of the samples analyzed here (Fig. 3, main text). These ages are found in the nearby basement granite intrusions of the Alumiador Suite (1800-1900 Ma) (Lacerda Filho et al., 2006; Redes et al., 2015; Redes et al., 2020; Santos et al., 2019) and gneiss of the Rio Apa Block (Fig. S12) (Cordani et al,. 2010; Redes et al., 2020; Teixeira et al., 2020; Ribeiro et al., 2020). Hence, these comprise the proximal sediment sources for the Jacadigo Group.

Mesoproterozoic to early Neoproterozoic ages (1600 to $900 \mathrm{Ma}$ ) for zircon grains in the samples are found in rocks related to the Sunsás, Aguapeí and Rodoniana-San Ignácio provinces of the southern Amazon Craton (Fig. S12) (Tassinari \& Macambira, 1999; Boger et al., 2005; Santos et al., 2008; Geraldes et al., 2014; Rizzotto et al., 2014; Teixeira et al., 2020). These are interpreted as the intermediately distant sources (Fig. 3, main text), several tens to a few hundred kilometers from the Jacadigo sedimentary basin.

The Amazon Craton lacks geochronological provinces characterized by Neoproterozoic ages younger than $900 \mathrm{Ma}$ (Fig. S12). However, recent studies have shown middle Tonian to early Cryogenian ages for magmatism within the North Paraguay Belt related to Rodinia breakup (Silva, 2018; Manoel et al., 2021). Coeval rocks along the SE border of the Amazon Craton are the likely distal sources for sediments of the Jacadigo Group (Fig. 3, main text). Following post-Sturtian glaciostatic rebound, denudation, and headward erosion, Marinoan glaciers advanced across regional drainage basins bringing distally sourced sediment to the Jacadigo sedimentary basin (Fig. 3, main text).

The youngest detrital zircon age dated in this study, of $690 \pm 18 \mathrm{Ma}$, is similar to the younger detrital zircon ages found in the Puga (Babinski et al., 2013; McGee et al., 2018) and Santa Cruz (Frei et al., 2017) formations. This not only indicates the existence of an Early Cryogenian source for the Cryogenian successions of the South Paraguay Belt, but also defines a maximum depositional age for the Jacadigo Group. 


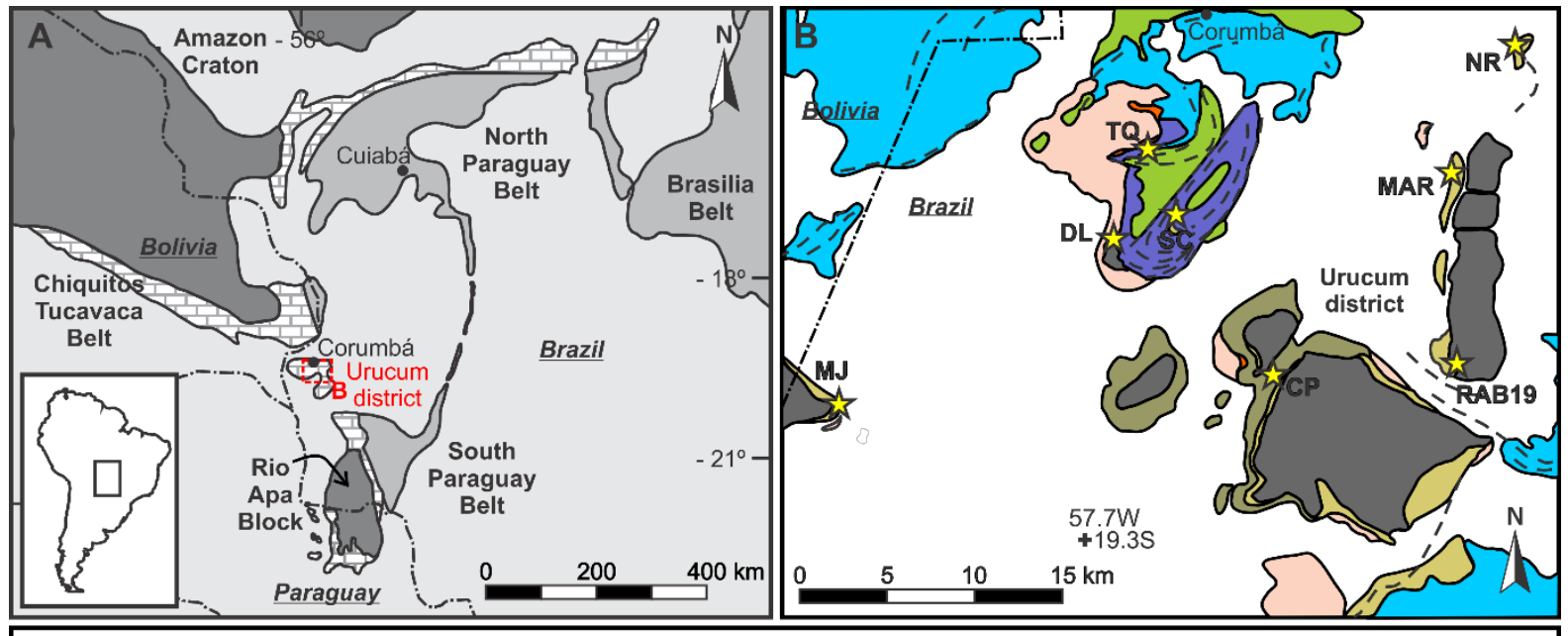

\begin{tabular}{|c|c|c|c|c|}
\hline \multicolumn{2}{|c|}{ Tectonic setting } & Symbols & Stratigraphic units & \\
\hline & Phanerozoic basins & - Cities & Urucum Fm. $(\mathrm{S} 2)^{*}$ & Cenozoic cover \\
\hline & Neoproterozoic fold and thrust belts & State borders & Urucum Fm. (S1 $\left.1_{\text {carbonate }}\right)$ & Tamengo Fm. (Ediacaran) \\
\hline 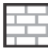 & Neoproterozoic cratonic covers & ל Columnar sections & Urucum Fm. ( $\left(\mathrm{S} 1_{\text {silicicasics }}\right)$ & Bocaina Fm. (Ediacaran) \\
\hline & Cratons & … Lineament & Basement & Santa Cruz Fm. (S2) \\
\hline
\end{tabular}

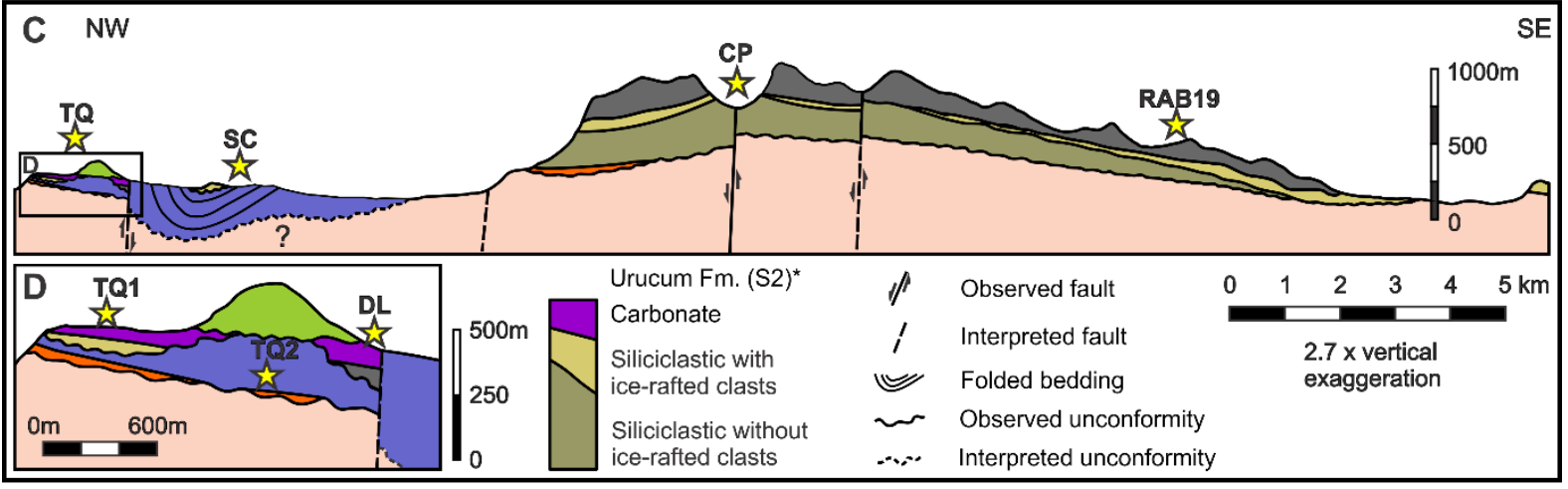

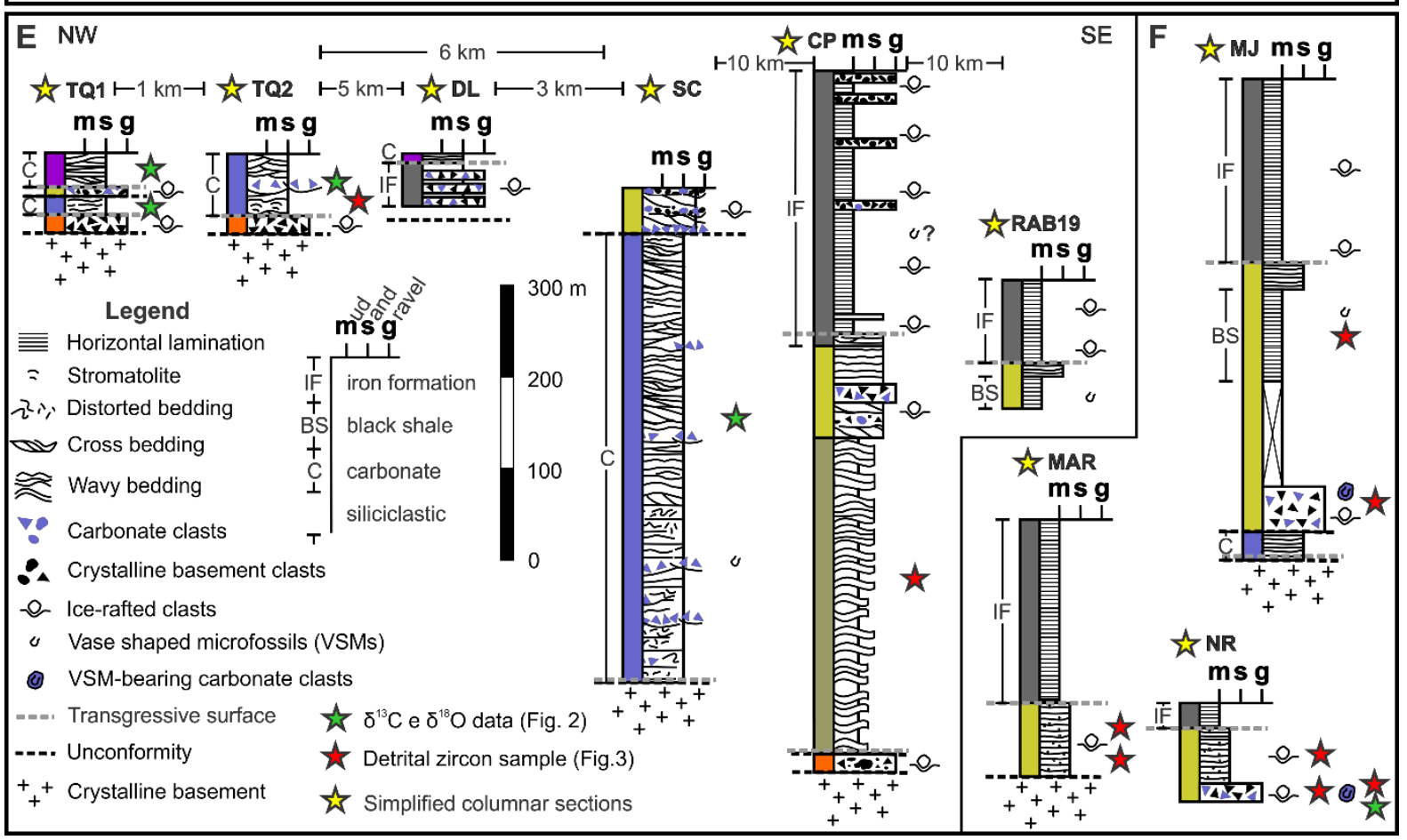


Figure S1. Geological sketch map and sections of the Urucum district area with locations of analyzed samples and sedimentary features discussed in the main text. A. Extended geological setting of the studied deposits. B. Geological sketch map of the Urucum district. C. NW-SE simplified geological section of the Urucum district with positions of columnar sections. D. Detail of C, highlighting paleovalleys mapped in the TQ area. E. Simplified columnar sections within the NW-SE section of the studied area. F. Simplified columnar sections of studied sedimentary successions outside the NW-SE section of the Urucum district. 


\section{Lower sequence (S1)}
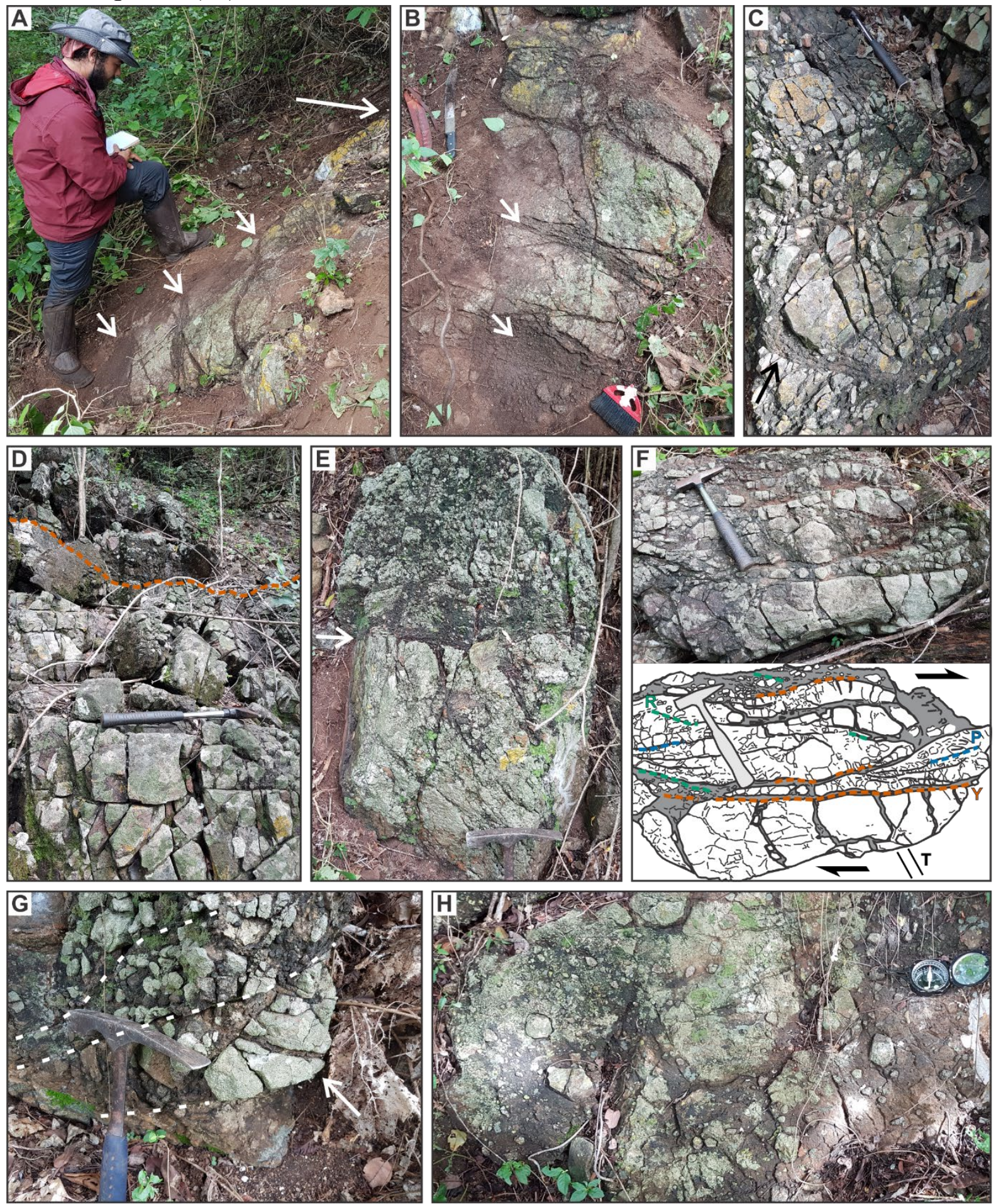

Figure S2. Common features at the base of the lower sequence (S1) of the Jacadigo Group (TQ area, Fig. S1). A. Oblique view of top of crystalline basement (large white arrow) showing subparallel, subvertical fractures (white arrows) filled by poorly sorted sediment. Note the higher density of fractures to the top (below large white arrow). B. Oblique plan view of A, highlighting subvertical lamination in fracture fillings (white arrows). The pebbles in the lower part of image are embedded in a sedimentary wedge within the fractured basement. C. Near plan view of vertical bedrock fractures filled by subvertically laminated, poorly sorted sediment (black arrow). D. Irregular contact (dashed red line) between highly 
fractured crystalline basement and poorly sorted sedimentary rock. E. Erosional unconformity (white arrow) at base of S1. F. Local brittle deformation near the top of the basement showing a downward decrease in fracture density. Note Riedel shear planes indicated by Y, P and $\mathrm{R}$, as well as tension fractures $(\mathrm{T})$ filled by poorly sorted sediment. Graphic interpretation indicates a dextral movement, here ascribed to subglacial deformation. G. Amalgamated thrust wedges (dashed white lines) in poorly sorted sedimentary rocks, locally displaying jigsaw fitting clasts (white arrow). H. Oblique view of structureless diamictite bed in the lower part of S1.
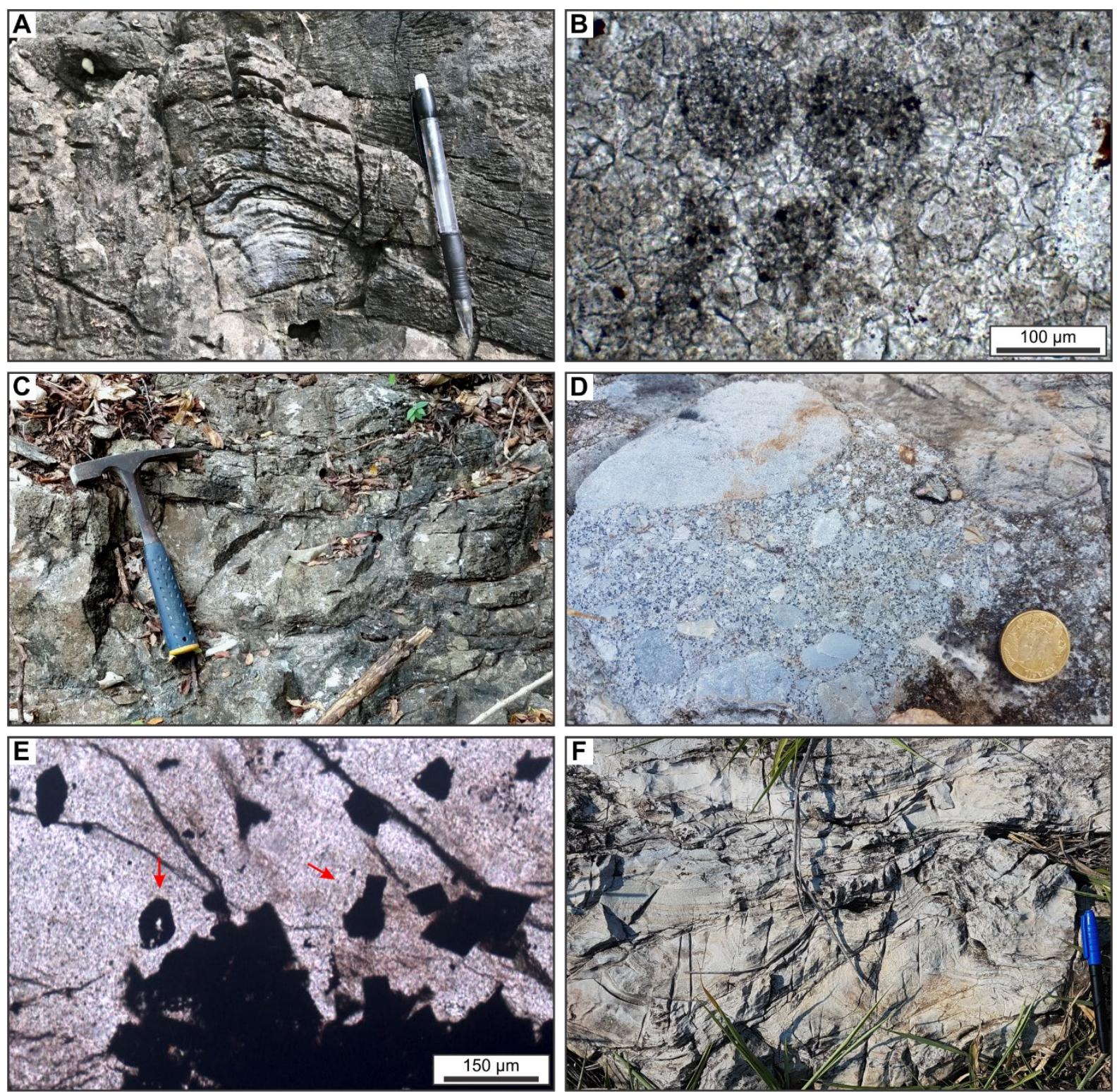

Figure S3. Features of facies in the carbonate succession of the lower sequence (S1) of the Jacadigo Group. A. Stratiform to domical stromatolite of carbonate shelf succession (TQ2 section, Fig. S1). B. Photomicrograph of microbialite in A, displaying three apparently acanthomorphic acritarchs within recrystallized dolomite. C. Fining and thinning upward decimeter-scale cycle with trough cross-stratification at the base and wavy and current 
lamination at the top (SC section, Fig. S1). D. Impure carbonate breccia with some rounded clasts (SC, Fig. S1). E. Photomicrograph of silicified carbonate exhibiting two vase-shaped microfossils (red arrows) as well as carbonate crystal pseudomorphs substituted by iron oxides (SC, Fig. S1). F. Soft sediment deformation folds in fine-grained carbonate beds (SC, Fig. S1).

\section{Upper sequence (S2)}
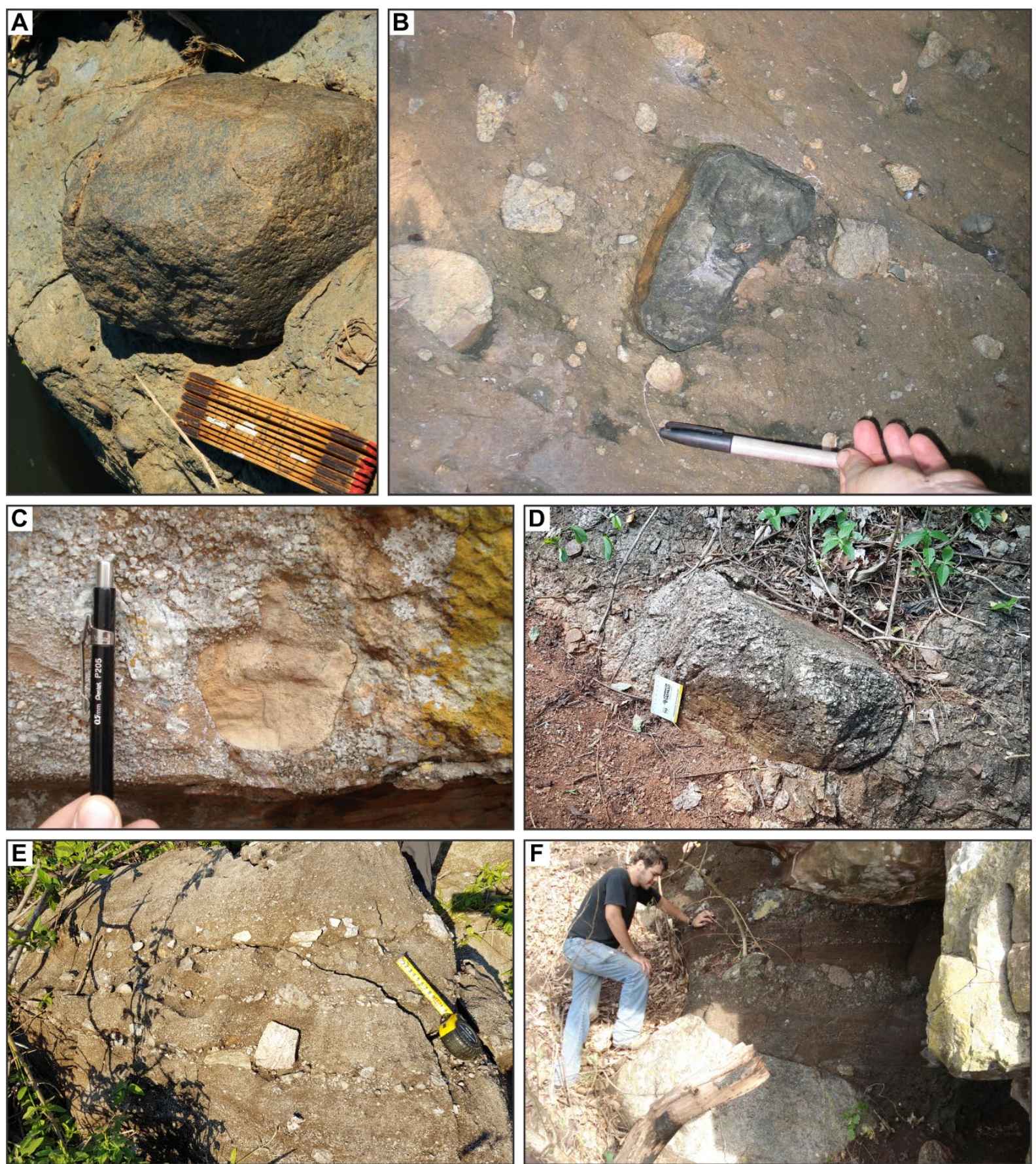

Figure S4. Outsized lonestones in siliciclastic successions of the upper sequence of the Jacadigo Group. A. Faceted granite boulder in diamictite (NR section, Fig. S1). B. Faceted carbonate cobble and granitoid pebbles within diamictite (NR, Fig. S1). C. Deformed 
sandstone clast within conglomeratic sandstone (ZN.01 section in Freitas et al., 2011). D. Striated and faceted boulder in basal polymictic sandy breccia (MJ, Fig. S1). E. Outsized pebbles in low-angle cross-stratified, graded, conglomeratic sandstone beds at the top of the interglacial carbonate succession of the Urucum Formation (SC, Fig. S1). F. Outsized granite boulder in graded sandstone succession at the top of the Urucum Formation (CP, Fig. S1; SD.01 section in Freitas et al., 2011).
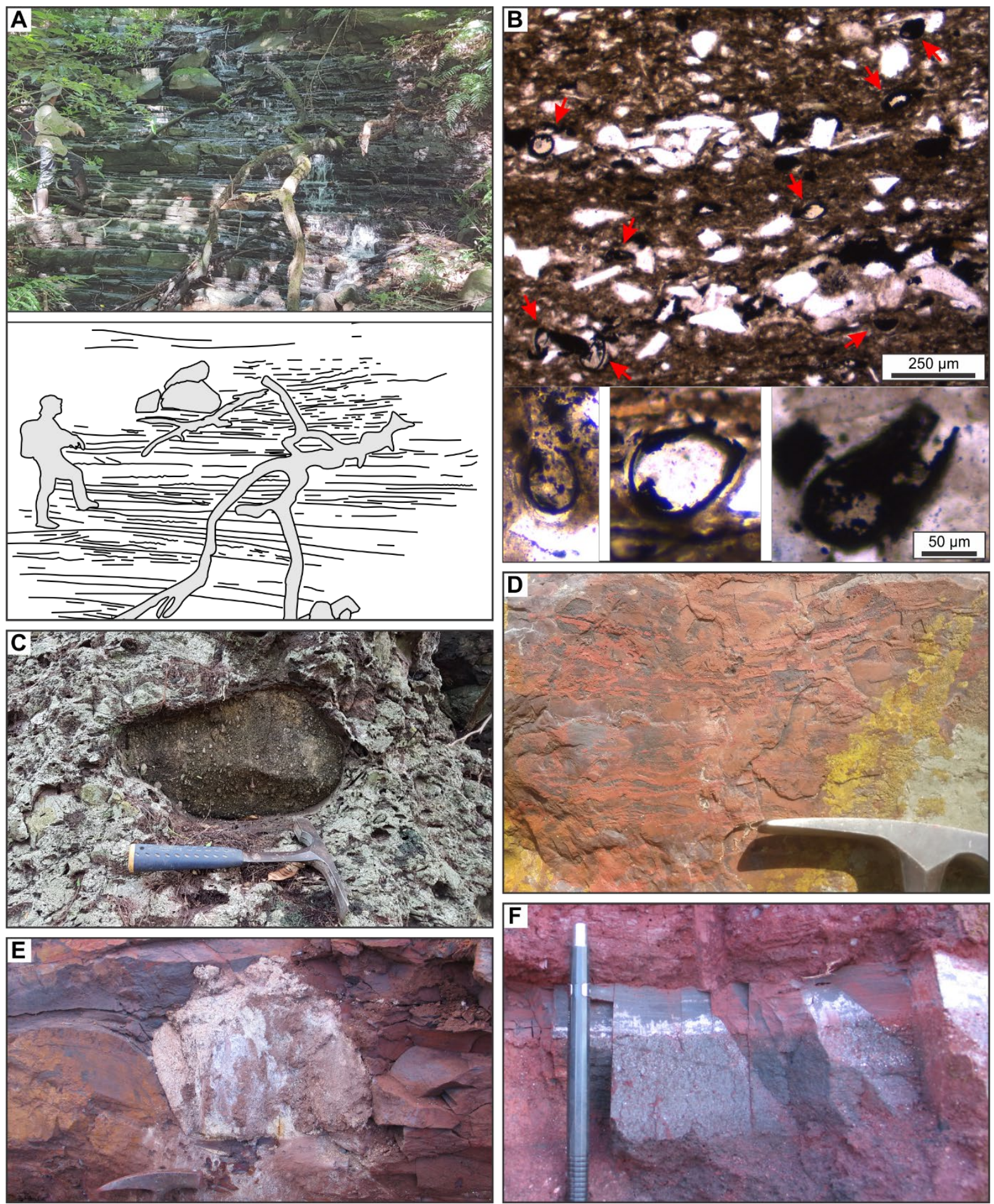
Figure S5. Features of facies in the Urucum and Santa Cruz formations. A. Sandy heterolithic deposit displaying wave ripples and wave bedding of meter-scale wavelength and decimeterscale amplitude (CP section, Fig. S1), detailed in line drawing. B. Photomicrograph of sandy black shale from drill core RAB-0019 at Rabicho hill (RAB19 section, Fig. S1) showing pyritized vase-shaped microfossils (red arrows) and scattered angular poorly sorted quartz grains, as well as details of three VSM specimens depicted in the same scale and from the same interval. C. Conglomeratic sandstone boulder within Fe-rich diamictite (between MAR and NR sections, Fig. S1). D. Ferruginized carbonate deposits displaying wave ripples and rip-up clasts (DL section, Fig. S1). E. Outsized granite lonestone and underlying deformed and disrupted laminations of the banded iron formation. F. Scattered poorly sorted sand and granule clasts in finely laminated iron formation (CP section, Fig. S1). 

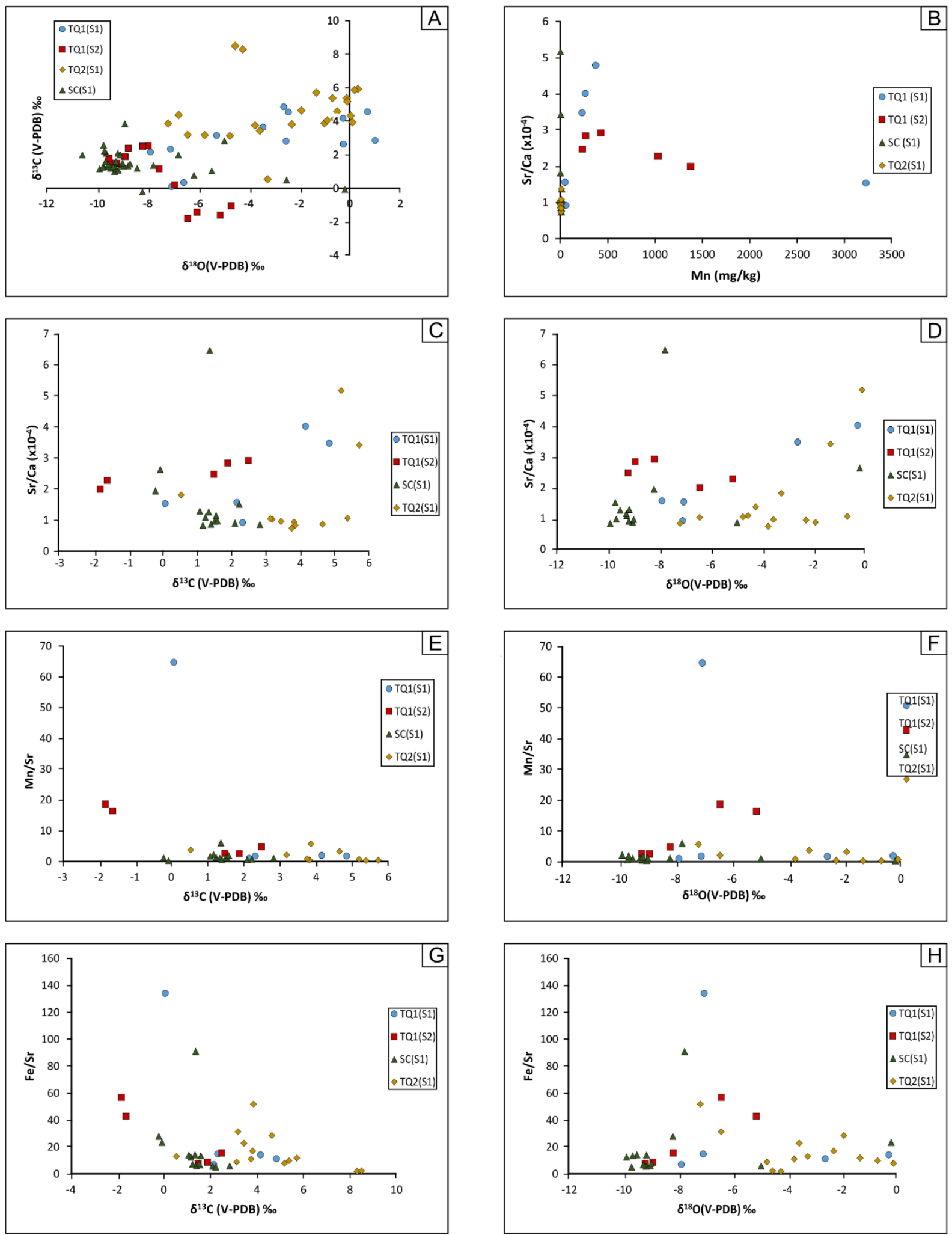

Figure S6. Geochemical proxies and relationships used to track post-depositional alteration of carbon and oxygen isotope signatures. A. $\delta^{13} \mathrm{C}$ vs $\delta^{18} \mathrm{O}$. B. Sr/Ca vs Mn. C. Sr/Ca vs $\delta^{13} \mathrm{C}$. D. $\mathrm{Sr} / \mathrm{Ca}$ vs $\delta^{18} \mathrm{O}$. E. Mn/Sr vs $\delta^{13} \mathrm{C}$. F. Mn/Sr vs $\delta^{18} \mathrm{O}$. G. Fe/Sr vs $\delta^{13} \mathrm{C} . \mathrm{H}$. Fe/Sr vs $\delta^{18} \mathrm{O}$. 


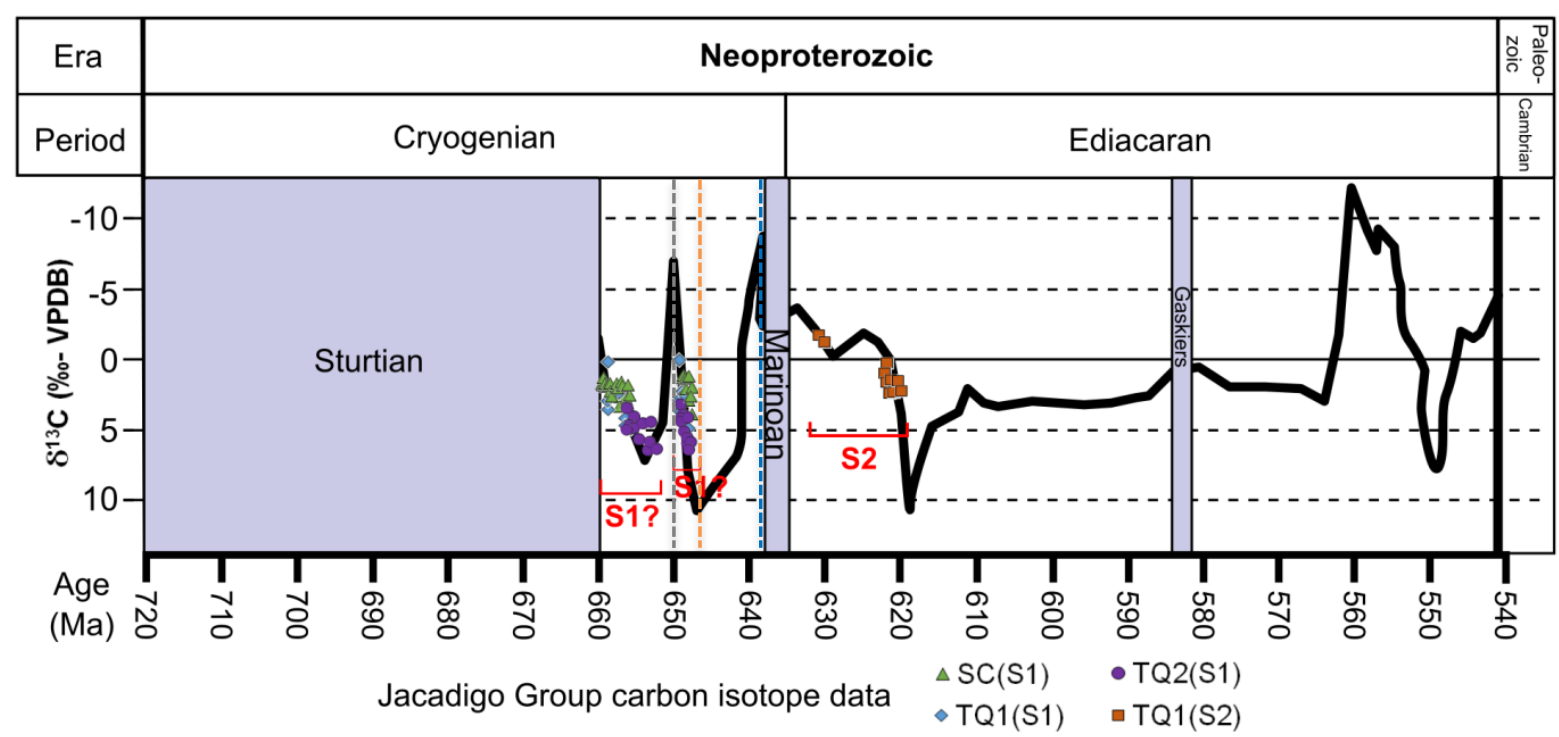

Figure S7. Correlation between post glacial $\delta^{13} \mathrm{C}$ data obtained for the Jacadigo Group and the composite $\delta^{13} \mathrm{C}$ curve compiled from previously published Cryogenian and Ediacaran results (modified from Ogg et al., 2016). Grey boxes represent glacial intervals. Vertical dashed lines mark the negative Taishir (gray) and Trezona (blue) peaks, and the positive Keele (orange) peak. 

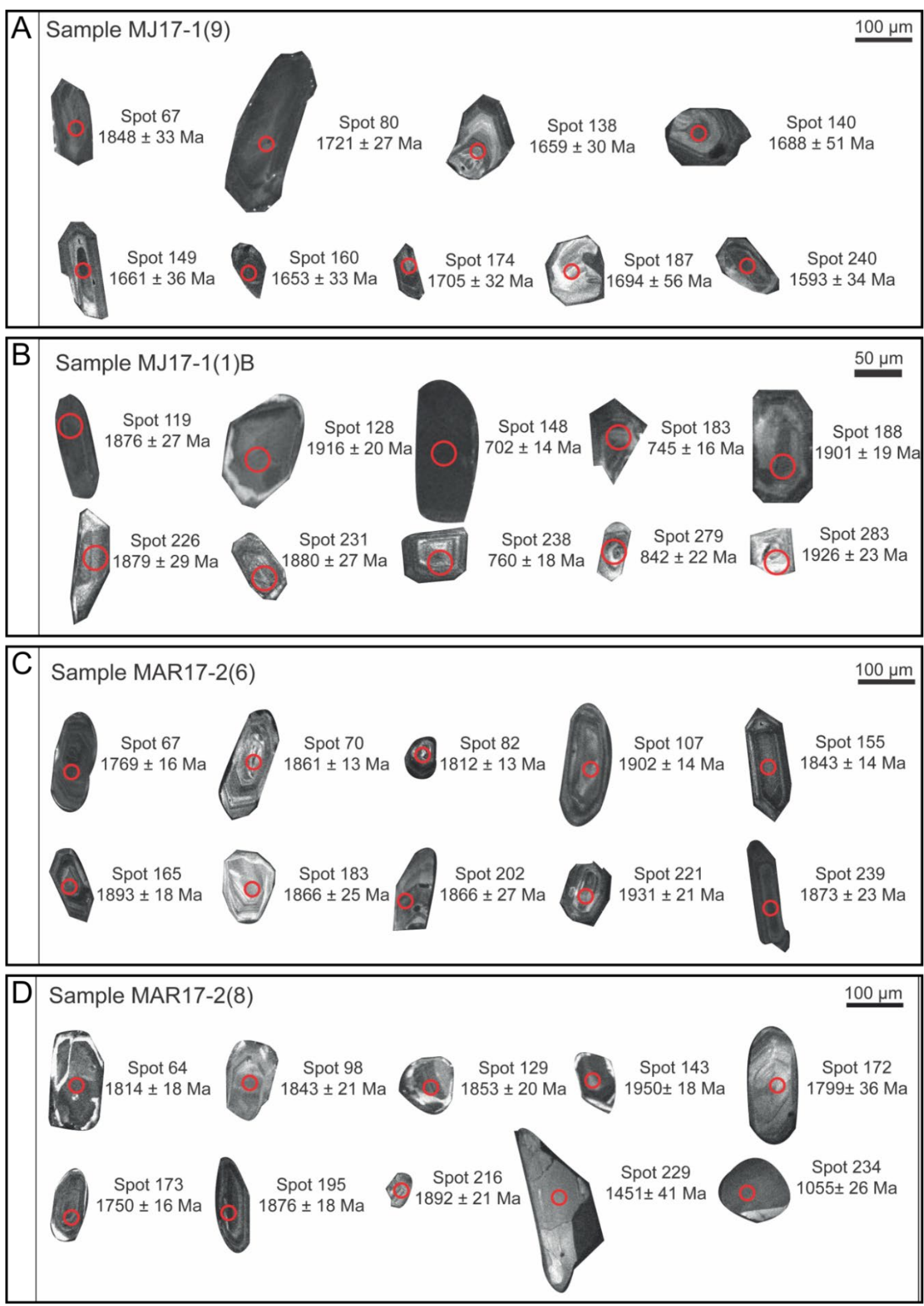

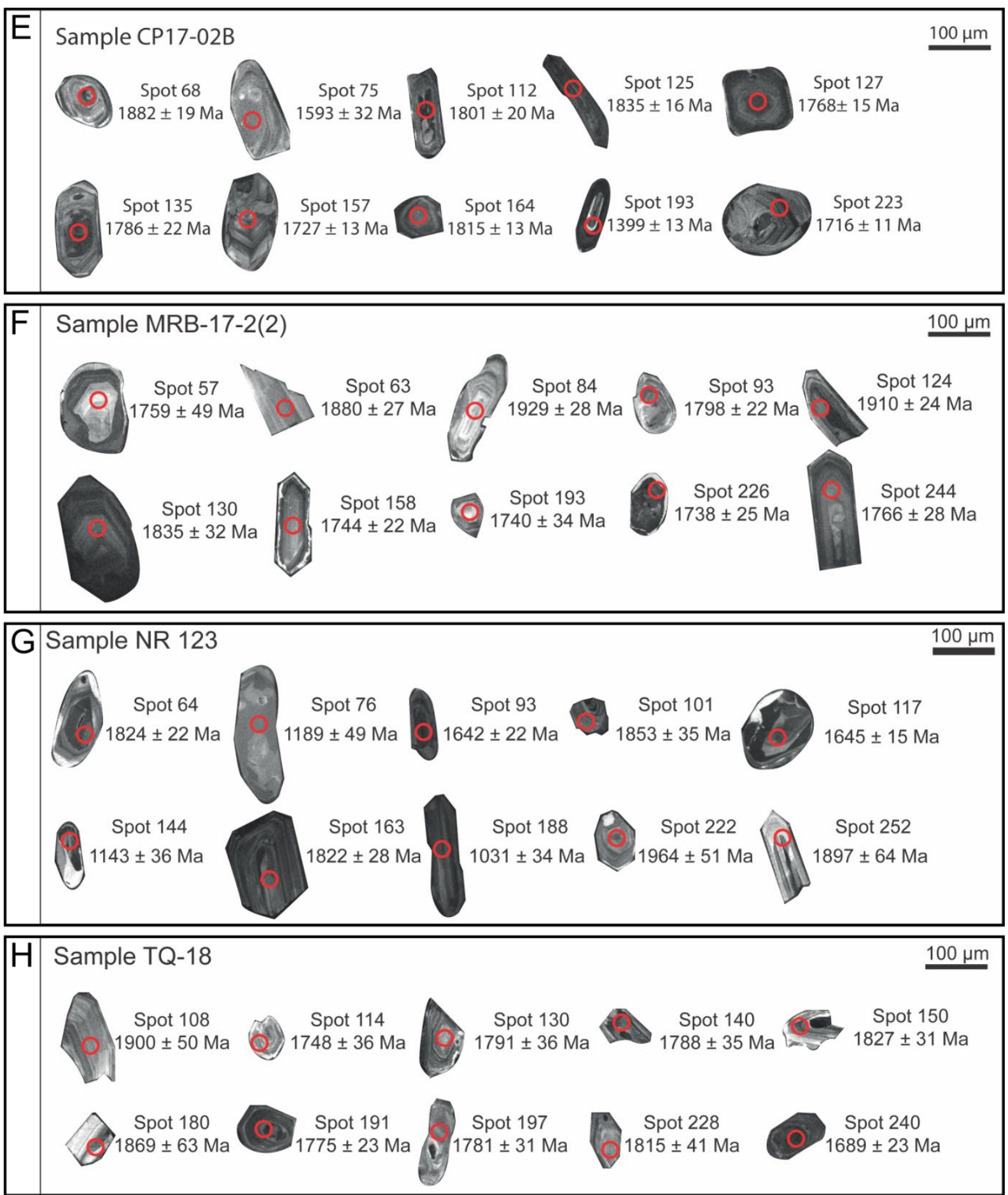

Figure S8. Cathodoluminescence images of zircon grains dated by LA-ICP-MS. Red circles mark beam spots. 


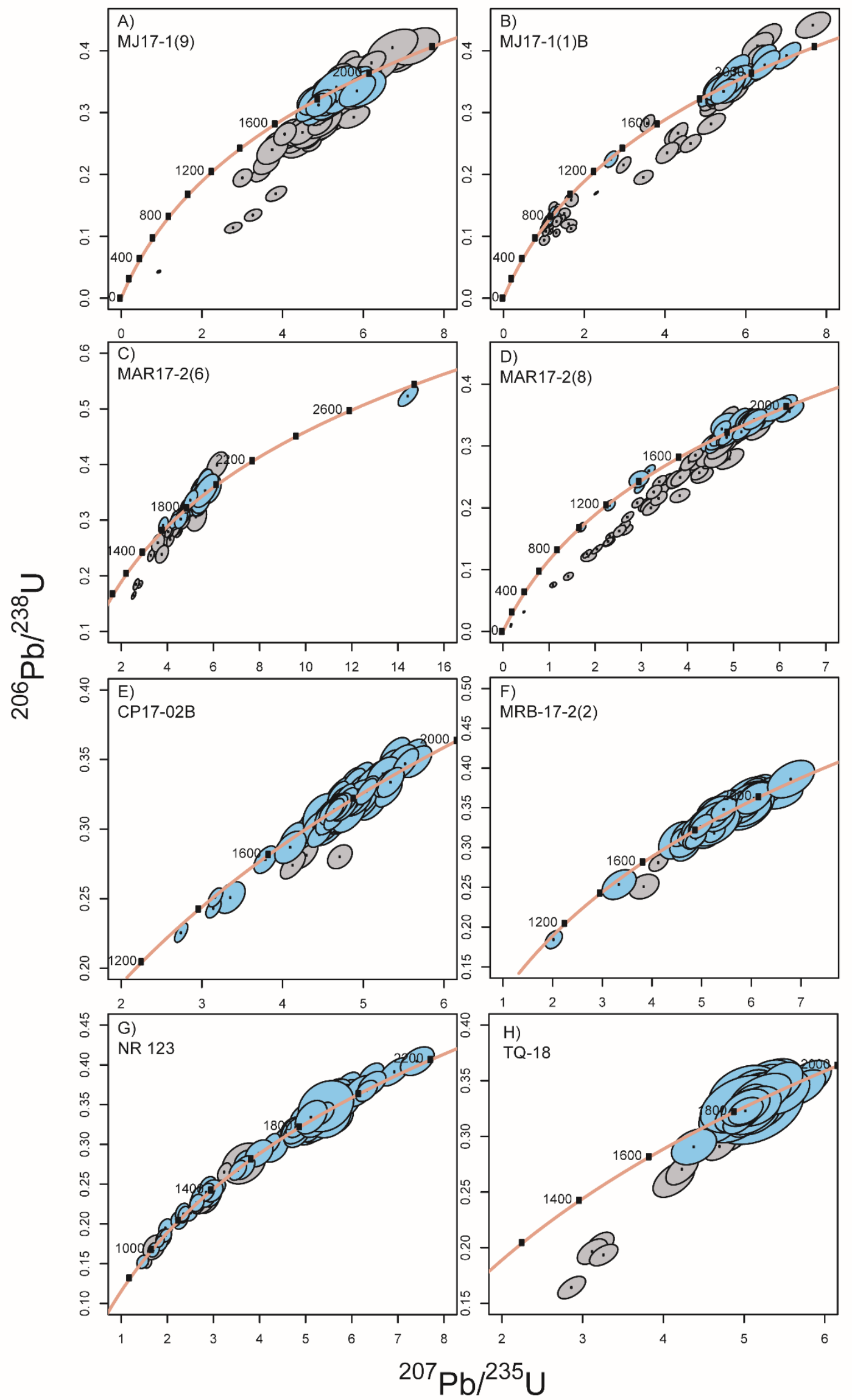

Figure S9. Concordia plots for samples analyzed by LA-ICP-MS. Blue ellipses indicate ages 
considered in the Probability Density Plot (Fig. 3, main text) and gray ellipses indicate discordant ages and ages excluded due to $\mathrm{Pb}$ loss.

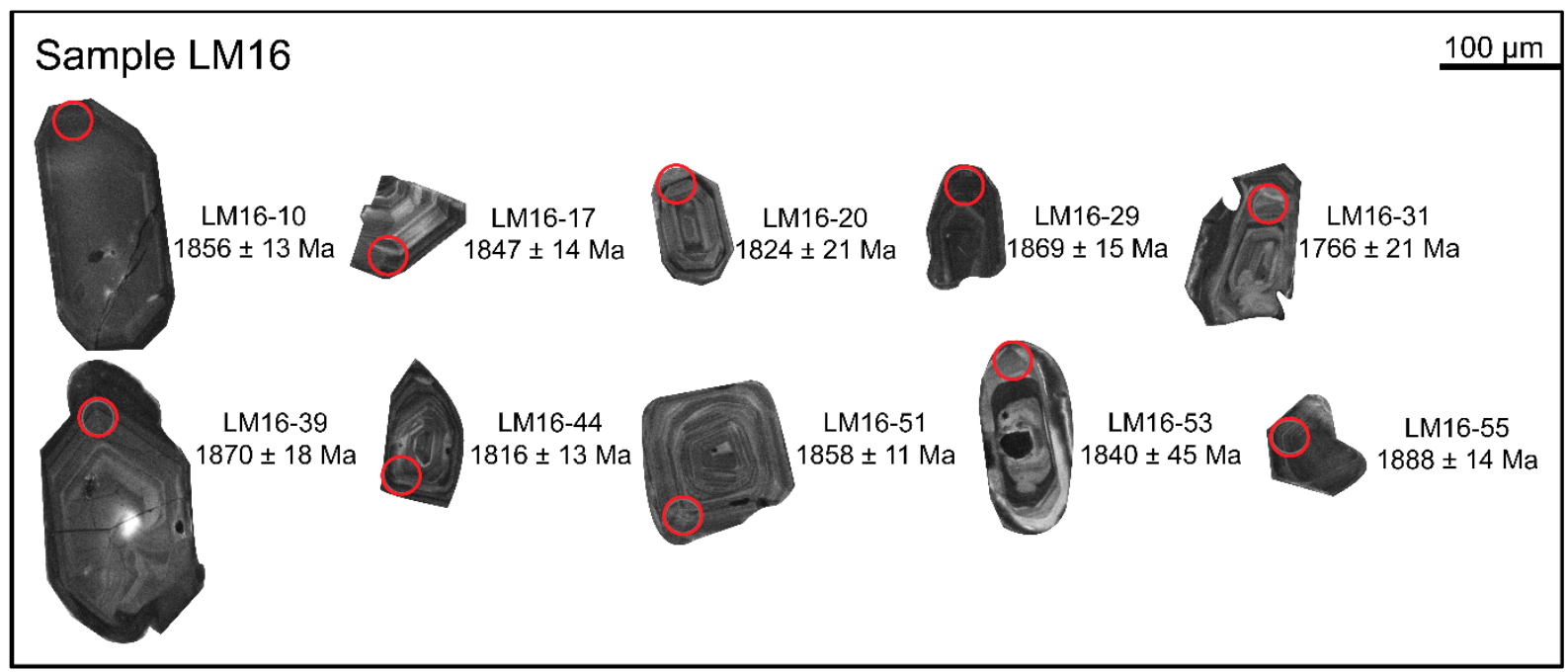

Figure S10. Cathodoluminescence images of zircon grains dated by SHRIMP. Red circles mark beam spots.

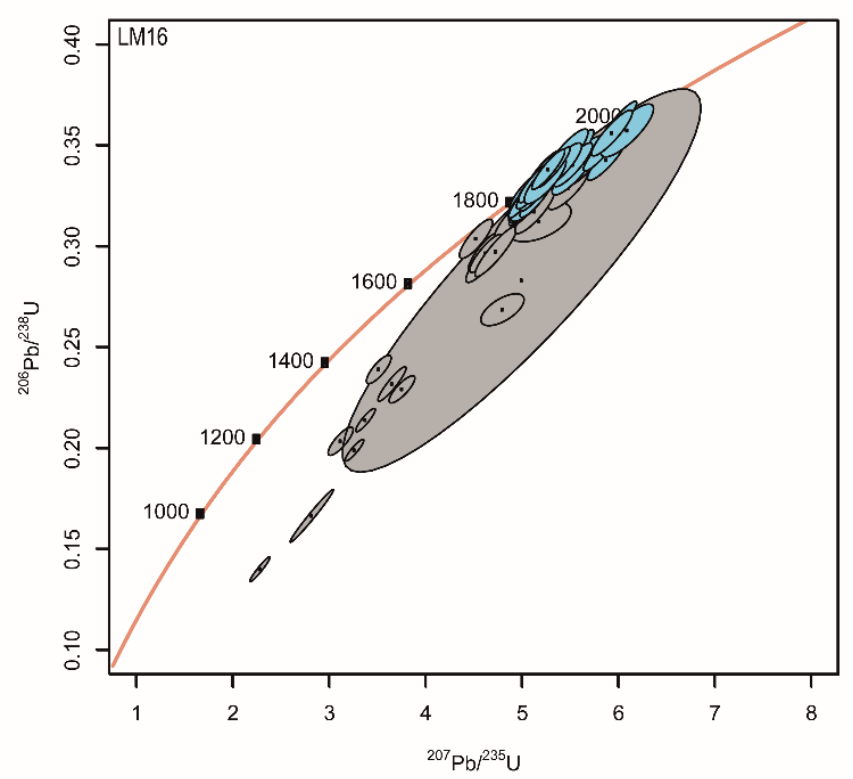

Figure S11. Concordia plot for sample LM16. Blue ellipses indicate results considered in the Probability Density Plot (Fig. 3, main text) and gray ellipses indicate discordant ages and ages excluded because of $\mathrm{Pb}$-loss. 


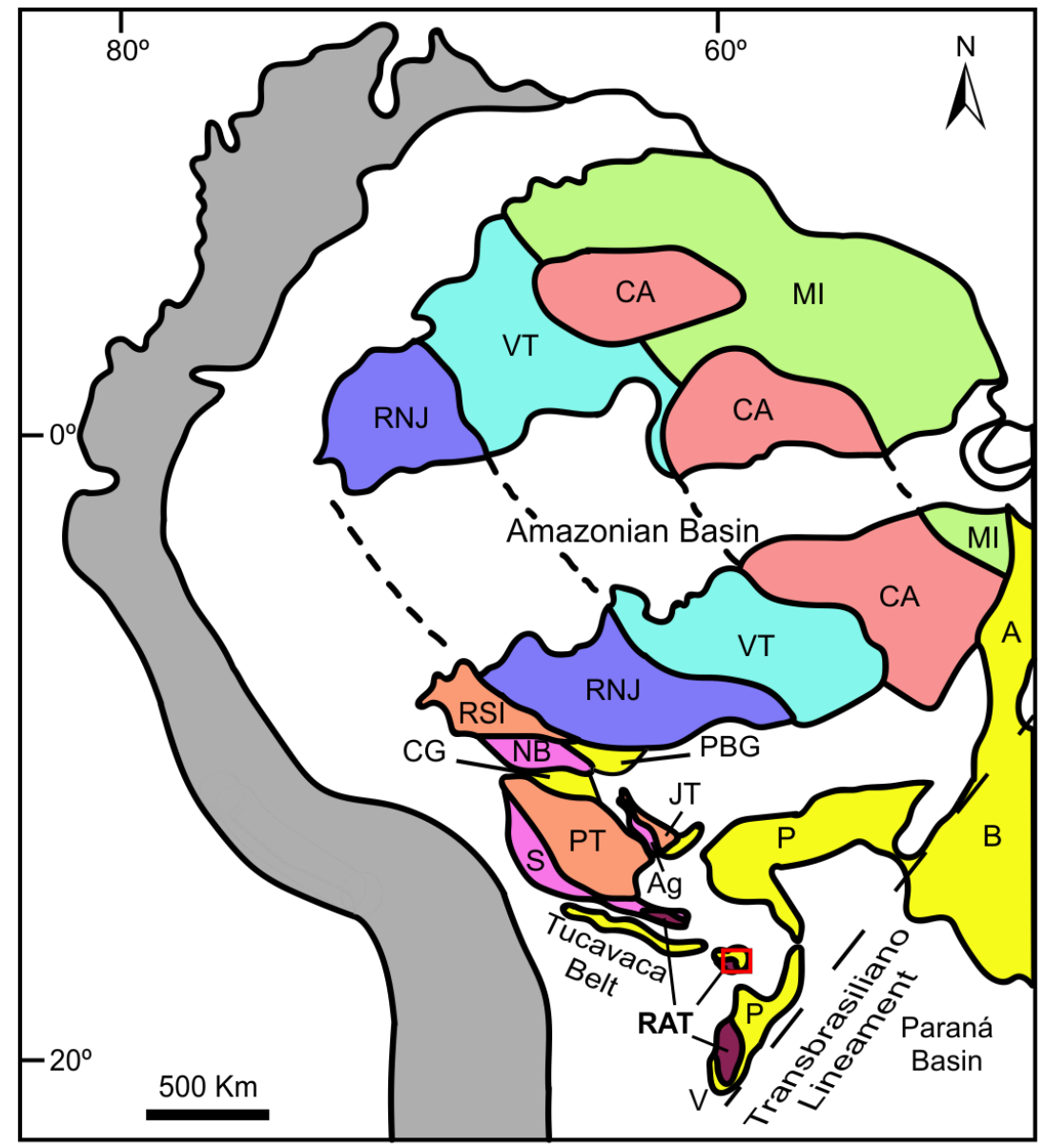

\section{LEGEND}

$\square$ Phanerozoic Sedimentary Cover Andean Belt

Study area

Neoproterozoic Belts (P - Paraguay, V - Valemi, A - Araguaia, $B$ - Brasília) and covers, including the Pimenta Bueno (PBG) and Colorado grabens (CG)

\section{Geochronological Provinces of the Amazonian Craton}

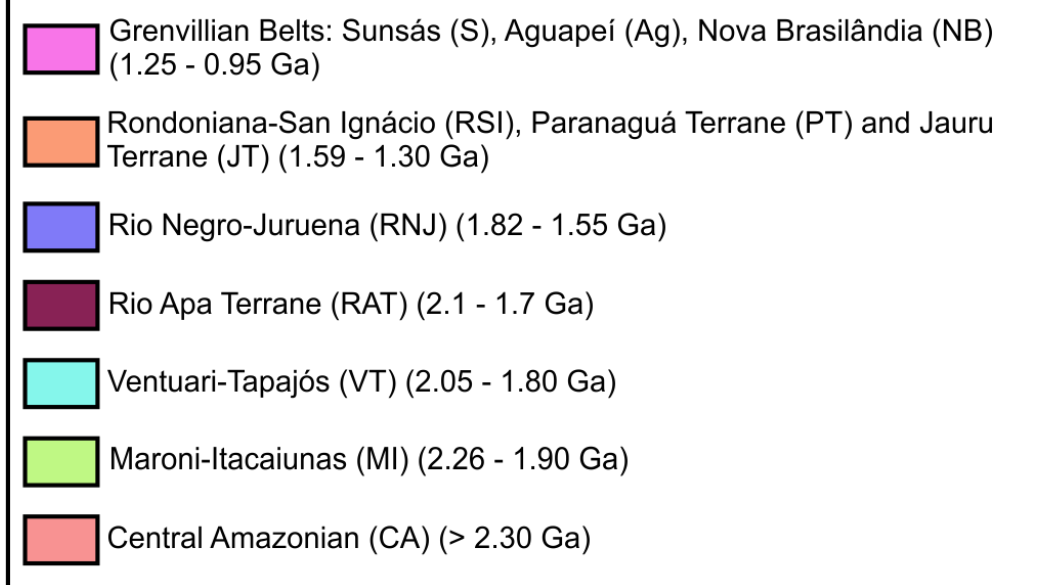

Figure S12. Geochronological provinces of the Amazonian Craton. After Tassinari \& Macambira (1999), Faleiros et al. (2016), Nogueira et al. (2019), Redes et al. (2020) and Teixeira et al. (2020). 
Table S1. Carbon and oxygen isotope data. Data in red are plotted on the C vs O dispersion chart, but not along columnar sections in Fig. 3 (main text), as they correspond to repeated analyses of certain stratigraphic levels. $72 \mathrm{H}$ means 72 hours under acid attack.

\begin{tabular}{|c|c|c|c|c|}
\hline Sample & $\begin{array}{l}\delta^{13} \mathrm{C}(\mathrm{V}- \\
\mathrm{PDB}) \% \mathrm{\%}\end{array}$ & $\begin{array}{l}\delta^{18} \mathrm{O}(\mathrm{V}- \\
\mathrm{PDB}) \%\end{array}$ & $\begin{array}{c}\text { Columnar } \\
\text { section }\end{array}$ & $\begin{array}{c}\text { Height } \\
(\mathrm{m}) \text { in } \\
\text { columnar } \\
\text { sections }\end{array}$ \\
\hline Rab-2014-1-P1 I68 & 6.72 & -1.4 & NR (clast) & -- \\
\hline Rab-2014-1-P2 I68 & 3.36 & -1.24 & NR (clast) & -- \\
\hline Rab-2014-9-P4A I68 & 3.42 & -2.78 & NR (clast) & -- \\
\hline Rab-2014-9-P4B I68 & 3.17 & -2 & NR (clast) & -- \\
\hline Rab-2014-14-P4 I68 & 6.52 & -1.18 & NR (clast) & -- \\
\hline 1(12-5-94)3A I68 & 3.97 & -2.74 & NR (clast) & -- \\
\hline 1(12-5-94)3B I68 & 3.62 & -2.59 & NR (clast) & -- \\
\hline $1(12-5-94) 4 \mathrm{~A}$ I68 & 3.81 & -4.35 & NR (clast) & -- \\
\hline 1(12-5-94)4B I68 & 7.39 & -1.65 & NR (clast) & -- \\
\hline 3(4-11-79)4A I68 & 7.51 & -1.01 & NR (clast) & -- \\
\hline 3(4-11-79)4B I68 & 6.92 & -1.51 & NR (clast) & -- \\
\hline 07TQ18-3B & 3.17 & -5.74 & TQ2(S1) & 0.8 \\
\hline 07TQ18-4 & 5.39 & -0.12 & TQ2(S1) & 4.8 \\
\hline 10TQ18-2 & 4.38 & -6.77 & TQ2(S1) & 0.9 \\
\hline 10TQ18-10 & 4.17 & -0.60 & TQ2(S1) & 1.35 \\
\hline 10TQ18-9 & 4.34 & 0.03 & TQ2(S1) & 2 \\
\hline 10TQ18-1 & 3.88 & -1.00 & TQ2(S1) & 2.4 \\
\hline 10TQ18-8 & 4.58 & -0.50 & TQ2(S1) & 2.4 \\
\hline 10TQ18-7 & 5.19 & -0.10 & TQ2(S1) & 3 \\
\hline 10TQ18-6 & 4.06 & -0.89 & TQ2(S1) & 3.7 \\
\hline 10TQ18-5 & 5.94 & 0.33 & TQ2(S1) & 4.5 \\
\hline 10TQ18-4 & 3.95 & 0.11 & TQ2(S1) & 5 \\
\hline 10TQ18-3 & 5.87 & 0.19 & TQ2(S1) & 6 \\
\hline 13TQ18-01 & 0.54 & -3.25 & TQ2(S1) & 12 \\
\hline 13TQ18-02 & 5.72 & -1.33 & TQ2(S1) & 13 \\
\hline 13TQ18-03 & 3.19 & -6.42 & TQ2(S1) & 14 \\
\hline 13TQ18-04 & 3.13 & -4.74 & TQ2(S1) & 15 \\
\hline 13TQ18-05 & 3.44 & -3.56 & TQ2(S1) & 16 \\
\hline 13TQ18-06 & 3.82 & -2.29 & TQ2(S1) & 17 \\
\hline 13TQ18-07 & 4.65 & -1.92 & TQ2(S1) & 18 \\
\hline 13TQ18-08 & 5.38 & -0.68 & TQ2(S1) & 19 \\
\hline 13TQ18-09 & 3.75 & -3.75 & TQ2(S1) & 20 \\
\hline 13TQ18-10 & 3.86 & -7.19 & TQ2(S1) & 21 \\
\hline 15TQ18-01 & 8.30 & -4.24 & TQ2(S1) & 46 \\
\hline 15TQ18-02 & 8.50 & -4.54 & TQ2(S1) & 46.5 \\
\hline 03TQ18-2A & 3.14 & -5.26 & TQ1(S1) & $?$ \\
\hline
\end{tabular}




\begin{tabular}{|c|c|c|c|c|}
\hline TQ01A & 0.08 & -7.04 & TQ1(S1) & 0 \\
\hline TQ01A (72h) & 0.34 & -6.56 & TQ1(S1) & 0 \\
\hline TQ01B & 2.85 & 1.01 & TQ1(S1) & 1 \\
\hline TQ01B (72h) & 3.63 & -3.43 & TQ1(S1) & 1 \\
\hline TQ01D & 2.63 & -0.25 & TQ1(S1) & 2.7 \\
\hline TQ01D (72h) & 2.8 & -2.51 & TQ1(S1) & 2.7 \\
\hline TQ01E & 2.16 & -7.88 & TQ1(S1) & 4.7 \\
\hline TQ01G & 2.33 & -7.08 & TQ1(S1) & 7 \\
\hline TQ01H & 4.16 & -0.26 & TQ1(S1) & 11 \\
\hline TQ01H (72h) & 4.56 & 0.71 & TQ1(S1) & 11 \\
\hline TQ01I & 4.85 & -2.6 & TQ1(S1) & 15 \\
\hline TQ01I (72h) & 4.54 & -2.42 & TQ1(S1) & 15 \\
\hline TQ01J & -1.81 & -6.41 & TQ1(S2) & 20 \\
\hline TQ01J (72h) & -1.43 & -6.03 & TQ1(S2) & 20 \\
\hline TQ01K & -1.61 & -5.12 & TQ1(S2) & 21.5 \\
\hline TQ01K (72h) & -1.06 & -4.68 & TQ1(S2) & 21.5 \\
\hline TQ01L & 1.15 & -7.54 & TQ1(S2) & 23 \\
\hline TQ01M & 0.2 & -6.92 & TQ1(S2) & 24.5 \\
\hline TQ01N & 1.88 & -8.87 & TQ1(S2) & 25.5 \\
\hline TQ010 & 2.54 & -7.97 & TQ1(S2) & 26.5 \\
\hline TQ01P & 1.5 & -9.48 & TQ1(S2) & 28 \\
\hline TQ01Q & 2.5 & -8.18 & TQ1(S2) & 30 \\
\hline TQ01R & 1.49 & -9.2 & TQ1(S2) & 33 \\
\hline TQ01S & 1.89 & -8.92 & TQ1(S2) & 34 \\
\hline TQ01T & 1.79 & -9.52 & TQ1(S2) & 35.5 \\
\hline TQ01T (72h) & 2.4 & -8.76 & TQ1(S2) & 35.5 \\
\hline 25SC18-1 & 1.24 & -9.26 & $\mathrm{SC}(\mathrm{S} 1)$ & 2 \\
\hline $25 \mathrm{SC} 18-2$ & 1.34 & -8.78 & $\mathrm{SC}(\mathrm{S} 1)$ & 20 \\
\hline $25 \mathrm{SC} 18-5$ & 1.34 & -9.52 & $\mathrm{SC}(\mathrm{S} 1)$ & 36 \\
\hline $25 \mathrm{SC} 18-8$ & 1.02 & -9.31 & $\mathrm{SC}(\mathrm{S} 1)$ & 51 \\
\hline 26SC18-1 & 1.17 & -9.9 & $\mathrm{SC}(\mathrm{S} 1)$ & 69 \\
\hline $26 \mathrm{SC} 18-4$ & 1.24 & -9.44 & $\mathrm{SC}(\mathrm{S} 1)$ & 88 \\
\hline $26 \mathrm{SC} 18-5$ & 1.4 & -9.03 & $\mathrm{SC}(\mathrm{S} 1)$ & 105 \\
\hline $26 \mathrm{SC} 18-8$ & 1.3 & -9.73 & $\mathrm{SC}(\mathrm{S} 1)$ & 121 \\
\hline 26SC18-9 & 2.1 & -9.18 & $\mathrm{SC}(\mathrm{S} 1)$ & 149 \\
\hline 26SC18-12 & 1.33 & -8.95 & $\mathrm{SC}(\mathrm{S} 1)$ & 171 \\
\hline $26 \mathrm{SC} 18-15$ & 1.27 & -9.77 & $\mathrm{SC}(\mathrm{S} 1)$ & 186 \\
\hline 26SC18-18 & 1.2 & -9.47 & $\mathrm{SC}(\mathrm{S} 1)$ & 204 \\
\hline $26 \mathrm{SC} 18-22$ & 2.1 & -9.64 & $\mathrm{SC}(\mathrm{S} 1)$ & 222 \\
\hline $27 \mathrm{SC} 18-2$ & 1.05 & -5.46 & $\mathrm{SC}(\mathrm{S} 1)$ & 242 \\
\hline $27 \mathrm{SC} 18-5$ & 1.55 & -9.28 & $\mathrm{SC}(\mathrm{S} 1)$ & 272 \\
\hline 27SC18-8 & 1.37 & -7.77 & $\mathrm{SC}(\mathrm{S} 1)$ & 302 \\
\hline $27 \mathrm{SC} 18-13$ & 1.2 & -8.41 & $\mathrm{SC}(\mathrm{S} 1)$ & 326 \\
\hline 27SC18-16 & 1.51 & -8.99 & $\mathrm{SC}(\mathrm{S} 1)$ & 346 \\
\hline
\end{tabular}




\begin{tabular}{lcclc}
$27 \mathrm{SC} 18-19$ & 2.23 & -9.71 & $\mathrm{SC}(\mathrm{S} 1)$ & 364 \\
$27 \mathrm{SC} 18-24$ & 2.83 & -4.96 & $\mathrm{SC}(\mathrm{S} 1)$ & 392 \\
$27 \mathrm{SC} 18-27$ & 1.47 & -8.69 & $\mathrm{SC}(\mathrm{S} 1)$ & 407 \\
$27 \mathrm{SC} 18-29$ & 1.08 & -9.16 & $\mathrm{SC}(\mathrm{S} 1)$ & 425 \\
$27 \mathrm{SC} 18-32$ & 1.22 & -9.26 & $\mathrm{SC}(\mathrm{S} 1)$ & 443 \\
$27 \mathrm{SC} 18-35$ & 2 & -9.09 & $\mathrm{SC}(\mathrm{S} 1)$ & 466 \\
$27 \mathrm{SC} 18-37$ & 2.58 & -9.74 & $\mathrm{SC}(\mathrm{S} 1)$ & 560 \\
$27 \mathrm{SC} 18-42$ & 1.29 & -9.36 & $\mathrm{SC}(\mathrm{S} 1)$ & 585 \\
$27 \mathrm{SC} 18-45$ & 2 & -6.78 & $\mathrm{SC}(\mathrm{S} 1)$ & 610 \\
$27 \mathrm{SC} 18-48$ & 3.85 & -8.9 & $\mathrm{SC}(\mathrm{S} 1)$ & 626 \\
$27 \mathrm{SC} 18-52$ & 1.61 & -9.25 & $\mathrm{SC}(\mathrm{S} 1)$ & 645 \\
$27 \mathrm{SC} 18-55$ & 2 & -10.58 & $\mathrm{SC}(\mathrm{S} 1)$ & 660 \\
$61 \mathrm{SC} 18-2$ & -0.21 & -8.20 & $\mathrm{SC}(\mathrm{S} 1)$ & 2 \\
$62 \mathrm{SC} 18-8$ & -0.07 & -0.19 & $\mathrm{SC}(\mathrm{S} 1)$ & 17 \\
$64 \mathrm{SC} 18-3$ & 0.49 & -2.50 & $\mathrm{SC}(\mathrm{S} 1)$ & 34 \\
$65 \mathrm{SC} 18-3$ & 0.77 & -6.17 & $\mathrm{SC}(\mathrm{S} 1)$ & 53 \\
$66 \mathrm{SC} 18-5$ & 1.43 & -9.56 & $\mathrm{SC}(\mathrm{S} 1)$ & 65 \\
$66 \mathrm{SC} 18-12$ & 1.59 & -9.67 & $\mathrm{SC}(\mathrm{S} 1)$ & 78 \\
\hline
\end{tabular}


Table S2. X-ray fluorescence results.

\begin{tabular}{|c|c|c|c|c|c|}
\hline Sample & Ca (\%) & $\mathrm{Fe}(\%)$ & $\begin{array}{c}\text { Mn } \\
(\mathrm{mg} / \mathrm{kg})\end{array}$ & $\begin{array}{c}\mathrm{Sr} \\
(\mathrm{mg} / \mathrm{kg})\end{array}$ & $\begin{array}{c}\text { Columnar } \\
\text { section }\end{array}$ \\
\hline 10TQ18-7 & 29.2 & 0.12 & 121 & 151 & TQ2(S1) \\
\hline 13TQ18-1 & 38.0 & 0.09 & 256 & 69 & TQ2(S1) \\
\hline 13TQ18-2 & 34.2 & 0.14 & 46 & 117 & TQ2(S1) \\
\hline 13TQ18-3 & 34.2 & 0.11 & 75 & 35 & TQ2(S1) \\
\hline 13TQ18-4 & 32.4 & 0.03 & $<\mathrm{LOD}$ & 34 & TQ2(S1) \\
\hline 13TQ18-5 & 36.7 & 0.08 & $<\mathrm{LOD}$ & 35 & TQ2(S1) \\
\hline 13TQ18-6 & 37.2 & 0.06 & 16 & 35 & TQ2(S1) \\
\hline 13TQ18-7 & 32.2 & 0.08 & 92 & 28 & TQ2(S1) \\
\hline 13TQ18-8 & 37.5 & 0.04 & 14 & 40 & TQ2(S1) \\
\hline 13TQ18-9 & 36.5 & 0.03 & 24 & 27 & TQ2(S1) \\
\hline 13TQ18-10 & 29.8 & 0.13 & 144 & 25 & TQ2(S1) \\
\hline 15TQ18-1 & 37.9 & 0.01 & $<\mathrm{LOD}$ & 52 & TQ2(S1) \\
\hline 15TQ18-2 & 38.7 & 0.01 & $<\mathrm{LOD}$ & 42 & TQ2(S1) \\
\hline TQ01A & 32.7 & 0.67 & 3231 & 50 & TQ1(S1) \\
\hline TQ01C & 36.8 & 0.23 & 374 & 176 & TQ1(S1) \\
\hline TQ01E & 36.6 & 0.04 & 52 & 57 & TQ1(S1) \\
\hline TQ01G & 37.3 & 0.05 & 59 & 34 & TQ1(S1) \\
\hline TQ01H & 35.4 & 0.20 & 265 & 142 & TQ1(S1) \\
\hline TQ01I & 39.2 & 0.15 & 232 & 136 & TQ1(S1) \\
\hline TQ01J & 37.2 & 0.42 & 1376 & 74 & TQ1(S2) \\
\hline TQ01K & 27.7 & 0.27 & 1033 & 63 & TQ1(S2) \\
\hline TQ01Q & 30.9 & 0.14 & 429 & 90 & TQ1(S2) \\
\hline TQ01R & 36.5 & 0.07 & 234 & 90 & TQ1(S2) \\
\hline TQ01S & 37.4 & 0.09 & 268 & 106 & TQ1(S2) \\
\hline 25SC18-1 & 37.8 & 0.03 & 51 & 41 & $\mathrm{SC}(\mathrm{S} 1)$ \\
\hline $25 \mathrm{SC} 18-5$ & 38.7 & 0.07 & 56 & 49 & $\mathrm{SC}(\mathrm{S} 1)$ \\
\hline $26 \mathrm{SC} 18-1$ & 38.2 & 0.04 & 72 & 32 & $\mathrm{SC}(\mathrm{S} 1)$ \\
\hline 26SC18-5 & 37.8 & 0.02 & 19 & 33 & $\mathrm{SC}(\mathrm{S} 1)$ \\
\hline 26SC18-9 & 38.7 & 0.02 & 21 & 35 & $\mathrm{SC}(\mathrm{S} 1)$ \\
\hline 27SC18-3 & 37.9 & 0.03 & 77 & 40 & $\mathrm{SC}(\mathrm{S} 1)$ \\
\hline $27 \mathrm{SC} 18-5$ & 39.1 & 0.03 & 45 & 45 & $\mathrm{SC}(\mathrm{S} 1)$ \\
\hline 27SC18-8 & 3.4 & 0.20 & 133 & 22 & $\mathrm{SC}(\mathrm{S} 1)$ \\
\hline 27SC18-16 & 39.3 & 0.03 & 46 & 38 & $\mathrm{SC}(\mathrm{S} 1)$ \\
\hline 27SC18-19 & 38.5 & 0.03 & 42 & 58 & $\mathrm{SC}(\mathrm{S} 1)$ \\
\hline 27SC18-24 & 39.6 & 0.02 & 39 & 34 & $\mathrm{SC}(\mathrm{S} 1)$ \\
\hline 27SC18-29 & 38.8 & 0.07 & 86 & 50 & $\mathrm{SC}(\mathrm{S} 1)$ \\
\hline 27SC18-49 & 39.2 & 0.02 & 15 & 42 & $\mathrm{SC}(\mathrm{S} 1)$ \\
\hline 61SC18-2 & 38.6 & 0.21 & 87 & 75 & $\mathrm{SC}(\mathrm{S} 1)$ \\
\hline 62SC18-2 & 35.0 & 0.46 & 48 & 68 & $\mathrm{SC}(\mathrm{S} 1)$ \\
\hline $62 \mathrm{SC} 18-8$ & 37.2 & 0.23 & 35 & 98 & $\mathrm{SC}(\mathrm{S} 1)$ \\
\hline 63SC18-1 & 42.3 & 0.02 & $<\mathrm{LOD}$ & 77 & $\mathrm{SC}(\mathrm{S} 1)$ \\
\hline
\end{tabular}




\begin{tabular}{lccccc}
$63 \mathrm{SC} 18-2$ & 35.9 & 0.17 & 59 & 105 & $\mathrm{SC}(\mathrm{S} 1)$ \\
$64 \mathrm{SC} 18-3$ & 35.3 & 0.35 & 99 & 124 & $\mathrm{SC}(\mathrm{S} 1)$ \\
$66 \mathrm{SC} 18-12$ & 37.8 & 0.05 & 72 & 37 & $\mathrm{SC}(\mathrm{S} 1)$ \\
\hline
\end{tabular}

Table S3 (separate xlx file). Detrital zircon (LA-ICP-MS and SHRIMP techniques) U-Pb geochronological results.

\section{SUPPLEMENTAL REFERENCES}

Babinski, M., Boggiani, P.C., Trindade, R.I.F., and Fanning, C.M., 2013, Detrital zircon ages and geochronological constraints on the Neoproterozoic Puga diamictites and associated BIFs in the southern Paraguay Belt, Brazil: Gondwana Research, v. 23, p. 988-997, doi:10.1016/j.gr.2012.06.011.

Banner, J.L., and Hanson, G., 1990, Calculation of simultaneous isotopic and trace element variations during water-rock interaction with applications to carbonate diagenesis: Geochimica et Cosmochimica Acta, v. 54, p. 3123-3137, doi:10.3382/ps.0731813.

Black, L.P., Kamo, S.L., Allen, C.M., Aleinikoff, J.N., Davis, D.W., Korsch, R.J., and Foudoulis, C., 2003, TEMORA 1: a new zircon standard for Phanerozoic U-Pb geochronology: Chemical Geology, v. 200, p. 155-170, doi:10.1016/S00092541(03)00165-7.

Boger, S.D., Raetz, M., Giles, D., Etchart, E., and Fanning, C.M., 2005, U-Pb age data from the Sunsás region of Eastern Bolivia, evidence for the allochthonous origin of the Paragua Block: Precambrian Research, v. 139 (3-4), p. 121-146, doi:10.1016/j.precamres.2005.05.010.

Boggiani, P.C., Ferreira, V.P., Sial, A.N., Babinski, M., Trindade, R.I.F., Aceñolaza, G., Toselli, A.J., and Parada, M.A., 2003, The cap carbonate of the Puga Hill (Central South America) in the context of the post-Varanger glaciation, in IV South American Symposium on Isotope Geology, Short Papers, Salvador, Brasil, v. 1, p. 324-327.

Broster, B.E., Dreimanis, A., White, J.C, 1979. A sequence of glacial deformation, erosion, and deposition at the ice-rock interface during the last glaciation: Cranbrook, British Columbia, Canada: Journal of Glaciology, v. 23 (89), p. 283-295.

Cordani, U.G., Teixeira, W., Tassinari, C., Coutinho, M.V.J., and Ruiz, A.S., 2010, The Rio Apa Craton in Mato Grosso do Sul (Brazil) and northern Paraguay: Geochronological evolution, correlations and tectonic implications for Rodinia and Gondwana: American Journal of Science, v. 310, p. 981-1023, doi:10.2475/09.2010.09

Czudek, T., 1995, Cryoplanation Terraces-A Brief Review and Some Remarks: Geografiska 
Annaler: Series A, Physical Geography, v. 77, p. 95-105, doi:10.1080/04353676.1995.11880431.

Faleiros, F.M., Pavan, M., Remédio, M.J., Rodrigues, J.B., Almeida, V.V., Caltabeloti, F.P., Pinto, L.G.R., Oliveira, A.A., Pinto de Azevedo, E.J., and Costa, V.S., 2016, Zircon $\mathrm{U}-\mathrm{Pb}$ ages of rocks from the Rio Apa cratonic terrane (Mato Grosso do Sul, Brazil): New insights for its connection with the Amazonian Craton in pre-Gondwana times: Gondwana Research, v. 34, p. 187-204, doi: 10.1016/j.gr.2015.02.018.

Fölling, P.G., and Frimmel, H.E., 2002, Chemostratigraphic correlation of carbonate successions in the Gariep and Saldania Belts, Namibia and South Africa: Basin Research, v. 14, p. 69-88, doi:10.1046/j.1365-2117.2002.00167.x.

Frei, R., Døssing, L.N., Gaucher, C., Boggiani, P.C., Frei, K.M., Bech Árting, T., Crowe, S.A., and Freitas, B.T., 2017, Extensive oxidative weathering in the aftermath of a late Neoproterozoic glaciation - Evidence from trace element and chromium isotope records in the Urucum district (Jacadigo Group) and Puga iron formations (Mato Grosso do Sul, Brazil): Gondwana Research, v. 49, p. 1-20, doi:10.1016/j.gr.2017.05.003.

Freitas, B.T., Warren, L.V., Boggiani, P.C., Almeida, R.P., and Piacentini, T., 2011, Tectonosedimentary evolution of the Neoproterozoic BIF-bearing Jacadigo Group, SWBrazil: Sedimentary Geology, v. 238, p. 48-70, doi:10.1016/j.sedgeo.2011.04.001.

Geraldes, M.C., Nogueira, C., Vargas-Mattos, G., Matos, R., Teixeira, W., Valencia, V., and Ruiz, J., 2014, U-Pb detrital zircon ages from the Aguapeí Group (Brazil): Implications for the geological evolution of the SW border of the Amazonian Craton: Precambrian Research, v. 244, p. 306-316, doi:10.1016/j.precamres.2014.02.001.

Halverson, G.P., and Shields-Zhou, G., 2011, Chemostratigraphy and the Neoproterozoic glaciations, in Arnaud, E.A., Halverson, G.P., and Shields-Zhou, G., eds., The Geological Record of Neoproterozoic Glaciations, Geological Society, London, Memoirs, v. 36, p. 51-66, doi:10.1144/M36.4

Harris, C., 1991, Glacially deformed bedrock at Wylfa Head, Anglesey, North Wales, in Forster, A., Culshaw, M.G., Cripps, J.C., Little, J. A., and Moon, C.F., eds., Quaternary Engineering Geology, Geological Society Engineering Geology Special Publication, v. 7, p. 135-142.

Hoefs, J., Müller, G., Schuster, K.A., and Walde, D., 1987, The FeMn ore deposits of Urucum, Brazil: An oxygen isotope study: Chemical Geology: Isotope Geoscience section, v. 65, p. 311-319, doi:10.1016/0168-9622(87)90011-X.

Hoffman, P.F., and Schrag, D.P., 2002, The snowball Earth hypothesis: testing the limits of global change, Terra Nova, v. 14 (3), p. 129-155, doi:10.1046/j.13653121.2002.00408.x.

Hudson, J.D., 1977, Stable isotopes and limestone lithification: Journal of Geological Society, v. 133, p. 637-660.

Huntley, J. W., Xiao, S., and Kowalewski, M., 2006, 1.3 billion years of acritarch history: an empirical morphospace approach: Precambrian Research, 144(1-2), 52-68.

Kah, L.C., 2000, Depositional $\mathrm{d}^{18} \mathrm{O}$ signatures in Proterozoic dolostones: Constraints on seawater chemistry and early diagenesis: SEPM Special Publication, v. 67, p. 345360, doi:10.2110/pec.00.67.0345. 
Knauth, L.P., and Kennedy, M.J., 2009, The late Precambrian greening of the Earth: Nature, v. 460, p. 728-732, doi:10.1038/nature08213.

Lacerda Filho, J.V., Brito, R.S.C., Silva, M.G., Oliveira, C.C., Moreton, L.C., Martins, E.G., Lopes, R.C., Lima, T.M., Larizatti, J.H., and Valente, C.R., 2006, Geologia e Recursos Minerais do Estado de Mato Grosso do Sul: Programa Integração, Atualização e Difusão de Dados da Geologia do Brasil, pp. 10-128.

Manoel, T.N., Selby, D., Galvez, M.E., Leite, J.A.D., and Figueiredo, L.N., 2021, A preSturtian depositional age of the lower Paraguay Belt, Western Brazil, and its relationship to western Gondwana magmatism: Gondwana Research, v. 89, p. 238 246, doi:10.1016/j.gr.2020.10.002.

McGee, B., Babinski, M., Trindade, R., and Collins, A.S., 2018, Tracing final Gondwana assembly: Age and provenance of key stratigraphic units in the southern Paraguay Belt, Brazil: Precambrian Research, v. 307, p. 1-33, doi:10.1016/j.precamres.2017.12.030.

Morais, L., Lahr, D.J.G., Rudnitzki, I.D., Freitas, B.T., Romero, G.R., Porter, S.M., Knoll, A.H., Fairchild, T.R., 2019, Insights into vase-shaped microfossil diversity and Neoproterozoic biostratigraphy in light of recent Brazilian discoveries: Journal of Paleontology, 93(4), 612-627.

Navarro, M.S., Tonetto, E.M., and Oliveira, E.P., 2017, Peixe zircon: new Brazilian reference material for U-Pb geochronology by LA-SF-ICP MS, in Goldschmidt Conference.

Nogueira, A.C.R., Romero, G.R., Sanchez, E.A.M., Domingos, F.H.G., Bandeira, J., Santos, I.M., Pinheiro, R.V.L., Soares, J.L., Lafon, J.M., Afonso, J.W.L., Santos, H.P., and Rudnitzki, I.D., 2019, The Cryogenian Ediacaran Boundary in the Southern Amazon Craton: Chemostratigraphy Across Major Chronological Boundaries, p. 89-114.

Ogg, J.G., Ogg, G.M., and Gradstein, F.M., 2016, Cryogenian and Ediacaran: A Concise Geologic Time Scale, p. 29-39, doi:10.1016/b978-0-444-59467-9.00004-2.

Passchier, S., Wilson, T.J., and Paulsen, T.S., 1998, Origin of breccias in the CRP-1 core: Terra Antartica, v. 5, p. 401-409.

Paton, C., Woodhead, J.D., Hellstrom, J.C., Hergt, J.M., Greig, A., and Maas, R., 2010, Improved laser ablation $\mathrm{U}-\mathrm{Pb}$ zircon geochronology through robust downhole fractionation correction: Geochemistry, Geophysics, Geosystems, v. 11, doi:10.1029/2009GC002618.

Piacentini, T., Vasconcelos, P.M., and Farley, K.A., 2013, ${ }^{40} \mathrm{Ar} /{ }^{39} \mathrm{Ar}$ constraints on the age and thermal history of the Urucum Neoproterozoic banded iron-formation, Brazil: Precambrian Research, v. 228, p. 48-62, doi:10.1016/j.precamres.2013.01.002.

Redes, L.A., Sousa, M.Z.A., Ruiz, A.S., and Lafon, J.-M., 2015, Petrogenesis and U-Pb and Sm-Nd geochronology of the Taquaral granite: record of an Orosirian continental magmatic arc in the region of Corumbá - MS: Brazilian Journal of Geology, v. 45, p. 431-451, doi:10.1590/2317-488920150030231.

Redes, L.A., Hauser, N., Ruiz, A.S., Matos, R., Reimold, W.U., Dantas, E.L., Schmitt, R.-T., Lima, B.A.F., Zacchi, E.N.P., Chaves, J.G.S., Osorio, L.F.B., and Pimentel, M.M., 2020, U-Pb and $\mathrm{Hf}$ isotopes in granitoids from the Eastern Bolivian basement: Insights into the Paleoproterozoic evolution of the western part of South America: Journal of South American Earth Sciences, v. 104, p. 102806, 
doi:10.1016/j.jsames.2020.102806.

Ribeiro, B.V., Cawood, P.A., Faleiros, F.M., Mulder, J.A., Martin, E., Finch, M.A., Raveggi, M., Teixeira, W., Cordani, U.G., and Pavan, M., 2020, A long-lived active margin revealed by zircon $\mathrm{U}-\mathrm{Pb}-\mathrm{Hf}$ data from the Rio Apa Terrane (Brazil): New insights into the Paleoproterozoic evolution of the Amazonian Craton: Precambrian Research, v. 350, p. 105919, doi:10.1016/j.precamres.2020.105919.

Riedman, L.A., Porter, S.M., and Calver, C.R., 2018, Vase-shaped microfossil biostratigraphy with new data from Tasmania, Svalbard, Greenland, Sweden and the Yukon: Precambrian Research, v. 319, p. 19-36, doi:10.1016/j.precamres.2017.09.019.

Riedman, L.A., Porter, S.M., Halverson, G.P., Hurtgen, M.T., and Junium, C.K., 2014, Organic-walled microfossil assemblages from glacial and interglacial Neoproterozoic units of Australia and Svalbard: Geology, 42(11), 1011-1014.

Rizzotto, G.J., Hartmann, L.A., Santos, J.O.S., and Mcnaughton, N.J., 2014, Tectonic evolution of the southern margin of the Amazonian craton in the late Mesoproterozoic based on field relationships and zircon $\mathrm{U}-\mathrm{Pb}$ geochronology: Anais da Academia Brasileira de Ciências, v. 86 (1), p. 57-84, doi:10.1590/0001-37652014104212.

Romero, G.R., Sanchez, E.A.M., Morais, L., Boggiani, P.C., and Fairchild, T.R., 2016, Tubestone microbialite association in the Ediacaran cap carbonates in the southern Paraguay Fold Belt (SW Brazil): Geobiological and stratigraphic implications for a Marinoan cap carbonate: Journal of South American Earth Sciences, v. 71, p. 172181, doi:10.1016/j.jsames.2016.06.014.

Santos, G., Ruiz, A.S., Sousa, M.Z.A., Batata, M.E.F., Cabrera, R.F., and Lafon, J.-M., 2019, Petrologia, deformação e geocronologia U-Pb (SHRIMP) do Granito Coimbra Bloco Rio Apa na região de Corumbá, Brasil: Geologia USP. Série Científica, v. 19, p. 171-192, doi:10.11606/issn.2316-9095.v19-138670.

Santos, J.O.S., Rizzotto, G.J., Potter, P.E., McNaughton, N.J., Matos, R.S., Hartmann, L.A., Chemale, F., and Quadros, M.E.S., 2008, Age and autochthonous evolution of the Sunsás Orogen in West Amazon Craton based on mapping and $\mathrm{U}-\mathrm{Pb}$ geochronology: Precambrian Research, v. 165(3-4), p. 120-152, doi:10.1016/j.precamres.2008.06.009.

Sato, K., Tassinari, C.C.G., Basei, M.A.S., Siga Júnior, O., and Onoe, A.T., 2014, Sensitive High Resolution Ion Microprobe (SHRIMP IIe/MC) of the Institute of Geosciences of the University of São Paulo, Brazil: method and first results: Geologia USP. Série Científica, v. 14, p. 3-18, doi:10.5327/Z1519-874X201400030001.

Sharman, G.R., Sharman, J.P., and Sylvester, Z., 2018, detritalPy: A Python-based toolset for visualizing and analysing detrital geo-thermochronologic data: The Depositional Record, v. 4, p. 202-215, doi:10.1002/dep2.45.

Shields-Zhou, G.A., Porter, S., and Halverson, G.P., 2016, A new rock-based definition for the Cryogenian Period (circa 720-635 Ma): Episodes , v. 39, p. 3-8, doi:10.18814/epiiugs/2016/v39i1/89231.

Silva, M.F., 2018, Evolução tectônica de rift para margem passiva da faixa Paraguai [PhD Thesis]: Universidade de Brasília, 198 p., http://rigeo.cprm.gov.br/jspui/handle/doc/20991 (accessed January 2020). 
Sláma, J., Košler, J., Condon, D.J., Crowley, J.L., Gerdes, A., Hanchar, J.M., Horstwood, M.S.A., Morris, G.A., Nasdala, L., Norberg, N., Schaltegger, U., Schoene, B., Tubrett, M.N., and Whitehouse, M.J., 2008, Plešovice zircon - A new natural reference material for $\mathrm{U}-\mathrm{Pb}$ and $\mathrm{Hf}$ isotopic microanalysis: Chemical Geology, v. 249, p. 1-35.

Tassinari, C.C.G., and Macambira, M.J.B., 1999, Geochronological provinces of the Amazonian Craton: Episodes, v. 22, p. 174-182.

Teixeira, W., Cordani, U.G., Faleiros, F.M., Sato, K., Maurer, V.C., Ruiz, A.S., and Azevedo, E.J.P., 2020, The Rio Apa Terrane reviewed: U-Pb zircon geochronology and provenance studies provide paleotectonic links with a growing Proterozoic Amazonia: Earth-Science Reviews, v. 202, p. 103089, doi:10.1016/j.earscirev.2020.103089.

Van der Wateren, F.M., Kluiving, S.J., and Bartek, L.R., 2000, Kinematic indicators of subglacial shearing, in Maltman, A.J., Hubbard, B., and Hambrey, M.J., eds., Deformation of glacial materials, Geological Society, London, special publications, v. 176, p. 259-278.

Vermeesch, P., 2018, IsoplotR: A free and open toolbox for geochronology: Geoscience Frontiers, v. 9, p. 1479-1493, doi:10.1016/j.gsf.2018.04.001.

Wiedenbeck, M., Allé, P., Corfu, F., Griffin, W.L., Meier, M., Oberli, F., Quadt, A.V., Roddick, J.C., and Spiegel, W., 1995, Three Natural Zircon Standards for U-Th-Pb, Lu-Hf, Trace Element and Ree Analyses: Geostandards Newsletter, v. 19, p. 1-23, doi:10.1111/j.1751-908X.1995.tb00147.x.

Williams, G.E., and Tonkin, D.G., 1985, Periglacial structures and palaeoclimatic significance of a late Precambrian block field in the Cattle Grid copper mine, Mount Gunson, South Australia: Australian Journal of Earth Sciences, v. 32, p. 287-300, doi:10.1080/08120098508729331.

Xiao, S., Zhang, Y., \& Knoll, A. H., 1998, Three-dimensional preservation of algae and animal embryos in a Neoproterozoic phosphorite: Nature, v. 391(6667), p. 553-558. 